Hydrogeologic Framework of Pennsylvanian and Late

\title{
Mississippian Rocks in the Central Lower Peninsula of Michigan
}

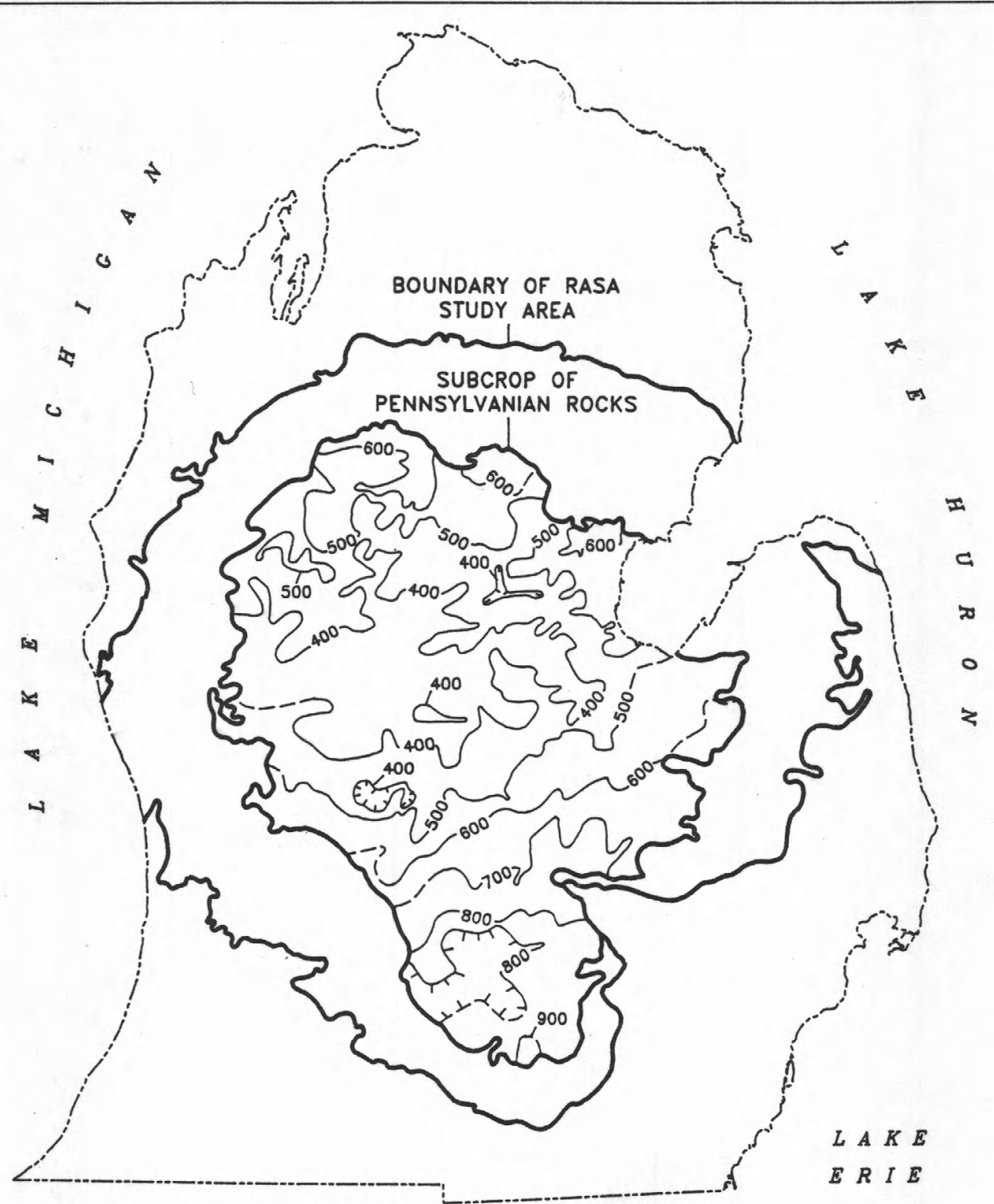

Michigan Basin Regional Aquifer-System Analysis

U.S. Geological Survey

Water-Resources Investigations Report 94-4107 
Cover illustration. From figure 5. 


\section{Hydrogeologic Framework of Pennsylvanian and Late Mississippian Rocks in the Central Lower Peninsula of Michigan}

By D.B. WESTJOHN and T.L. WEAVER

U.S. GEOLOGICAL SURVEY

Water-Resources Investigations Report 94-4107 


\title{
U.S. DEPARTMENT OF THE INTERIOR BRUCE BABBITT, Secretary
}

\author{
U.S. GEOLOGICAL SURVEY \\ Gordon P. Eaton, Director
}

For additional information write to:

\section{District Chief}

U.S. Geological Survey, WRD 6520 Mercantile Way, Suite 5 Lansing, MI 48911
Copies of this report may be purchased from:

\author{
U.S. Geological Survey \\ Earth Science Information Center \\ Open-File Reports Section \\ Box 25286, MS 517 \\ Denver Federal Center \\ Denver, Colorado 80225
}




\section{CONTENTS}

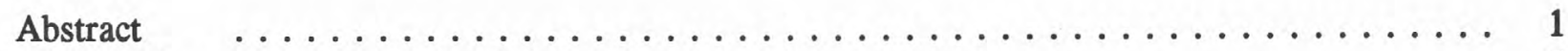

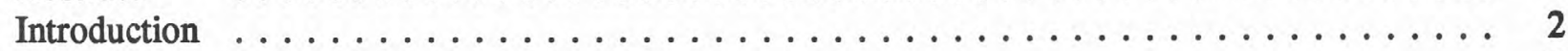

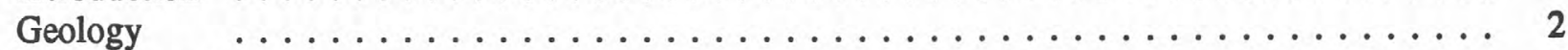

Bayport Limestone . . . . . . . . . . . . . . . . . . . . . 6

Parma Sandstone ........................... 6

Saginaw and Grand River Formations .................... 7

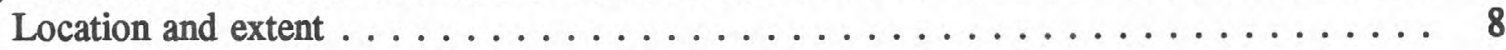

Relations of stratigraphic units to aquifer and confining units . . . . . . . . . . 8

Delineation of aquifer- and confining-unit boundaries $\ldots \ldots \ldots \ldots \ldots \ldots \ldots$

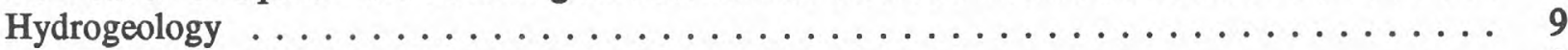

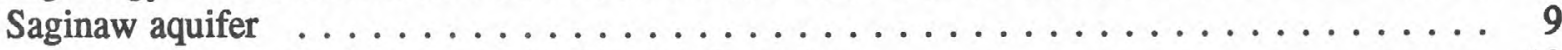

Areal extent, thickness, and surface configuration ................ 12

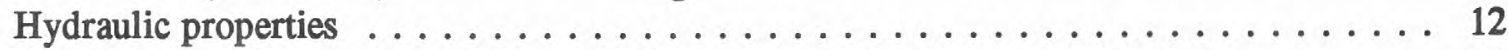

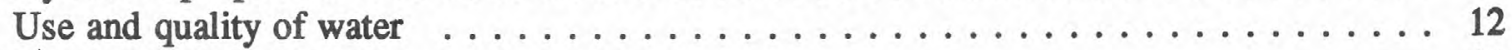

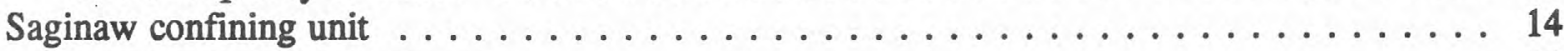

Areal extent and thickness . . . . . . . . . . . . . . . . . 14

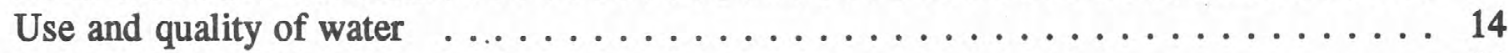

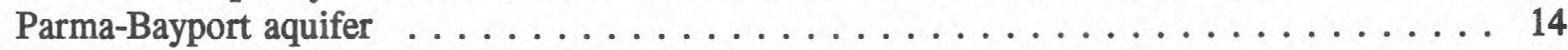

Areal extent, thickness, and surface configuration $\ldots \ldots \ldots \ldots \ldots \ldots \ldots \ldots$

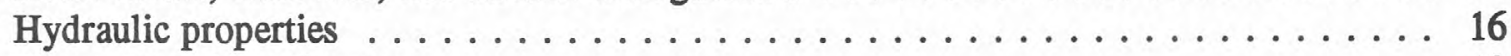

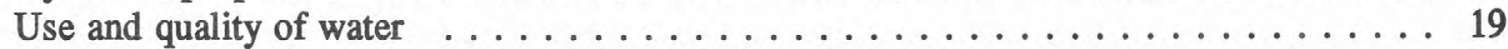

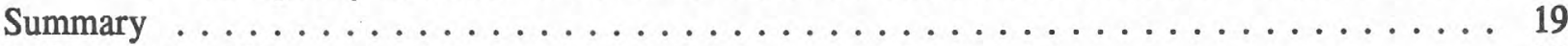

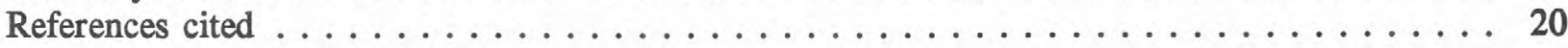

APPENDIXES

A. Identification and locations of geophysical and geologic logs, and generalized

hydrogeologic sections illustrating relations of aquifer and confining units $\ldots \ldots \ldots 25$

B. Interpretation of geophysical and geologic $\operatorname{logs} \ldots \ldots \ldots \ldots \ldots \ldots \ldots$

C. Locations of boreholes and $\operatorname{logs} \ldots \ldots \ldots \ldots \ldots \ldots \ldots$ 


\section{FIGURES}

1. Map of Lower Peninsula of Michigan and Michigan Basin Regional Aquifer-System

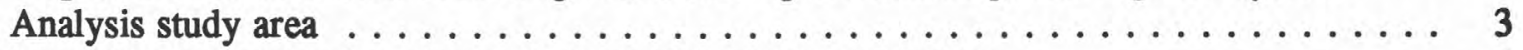

2. Map showing bedrock geology of Lower Peninsula of Michigan . . . . . . . . . . 4

3. Diagram showing Mississippian through Pleistocene stratigraphic nomenclature,

hydrogeologic units, and rock units in the central Lower Peninsula of Michigan . . . . . 5

4-9. Maps showing:

4. Thickness of Pennsylvanian rocks in the central Lower Peninsula of Michigan . . . . 10

5. Surface configuration of Pennsylvanian rocks in the central Lower

Peninsula of Michigan . . . . . . . . . . . . . . . . 11

6. Thickness of Saginaw aquifer in the central Lower Peninsula of Michigan . . . . . 13

7. Thickness of Saginaw confining unit in the central Lower Peninsula of Michigan ... 15

8. Thickness of Parma-Bayport aquifer in the central Lower Peninsula of Michigan ... 17

9. Surface configuration of Parma-Bayport aquifer in the central Lower

Peninsula of Michigan $\ldots \ldots \ldots \ldots \ldots \ldots \ldots \ldots \ldots$

\section{CONVERSION FACTORS}

\begin{tabular}{rll}
\hline Multiply & By & To obtain \\
foot $(\mathrm{ft})$ & 0.3048 & meter \\
foot $(\mathrm{ft})$ & 30.48 & centimeter \\
mile $(\mathrm{mi})$ & 1.609 & kilometer \\
square mile $\left(\mathrm{mi}^{2}\right)$ & 2.590 & square kilometer \\
gallon $(\mathrm{gal})$ & 0.1337 & cubic foot \\
gallon $(\mathrm{gal})$ & 0.003785 & cubic meter \\
feet per day $(\mathrm{tt} / \mathrm{d})$ & 0.0003528 & centimeter per second \\
foot squared per day $\left(\mathrm{ft}^{2} / \mathrm{d}\right)$ & 0.0009299 & meter squared per day \\
gallon per day per foot $\left[\left(\mathrm{gal}^{\mathrm{d}}\right) / \mathrm{ft}\right]$ & 0.01242 & meter squared per day \\
million gallons per day $(\mathrm{Mgal} / \mathrm{d})$ & 3,785 & cubic meter per day
\end{tabular}

Sea level: In this report "sea level" refers to the National Geodetic Vertical Datum of 1929 (NGVD of 1929)-a geodetic datum derived from a general adjustment of the first-order level nets of both the United States and Canada, formerly called Sea Level Datum of 1929.

Abbreviated water-quality units used in this report: Chemical concentration is given in milligrams per liter (mg/L) or micrograms per liter $(\mu \mathrm{g} / \mathrm{L})$. Milligrams per liter is a unit expressing the concentration of chemical constituents in solution as weight (milligrams) of solute per unit volume (liter) of water. One thousand micrograms per liter is equivalent to one milligram per liter. For concentrations less than $7,000 \mathrm{mg} / \mathrm{L}$, the numerical value is the same as for concentrations in parts per million.

Another abbreviation in this report is centimeters per second $(\mathrm{cm} / \mathrm{s})$.

${ }^{1} \mathrm{Hydraulic}$ conductivity by definition is given in units of cubic feet per day per square foot $\left[\left(\mathrm{ft}^{3} / \mathrm{d}\right) / \mathrm{ft}^{2}\right]$, which is mathematically equivalent to (ft/d).

${ }^{2}$ Transmissivity by definition should be given in units of cubic feet per day per foot $\left[\left(\mathrm{ft}^{3} / \mathrm{d}\right) / \mathrm{ft}\right]$, which is mathematically equivalent to $\left(\mathrm{ft}^{2} / \mathrm{d}\right)$.

iv Hydrogeologic Framework of Pennsylvanian and Late Mississippian

Rocks in the Central Lower Peninsula of Michigan 


\title{
Hydrogeologic Framework of Pennsylvanian and Late Mississippian Rocks in the Central Lower Peninsula of Michigan
}

\author{
By D.B. Westjohn and T.L. Weaver
}

\begin{abstract}
Late Mississippian and Pennsylvanian sedimentary rocks form part of a regional system of aquifers and confining units in the central Lower Peninsula of Michigan. The upper part of the Pennsylvanian rock sequence constitutes the Saginaw aquifer, which consists primarily of sandstone. This sandstone aquifer overlies the Saginaw confining unit, which consists primarily of shale. The Saginaw confining unit separates the Saginaw aquifer from the Parma-Bayport aquifer, which consists primarily of permeable sandstones and carbonates; these permeable units are interpreted to be hydraulically connected and stratigraphically continuous at the scale of the regional aquifer system.
\end{abstract}

The Saginaw aquifer ranges in thickness from 100 to 370 feet along a 30 - to 45 -milewide south-trending corridor through the approximate center of the aquifer system. The Saginaw aquifer typically contains freshwater along this corridor of thick sandstone. Most municipalities that use water from the Saginaw aquifer are located along this corridor. On either side of this corridor, the Saginaw aquifer generally is less than 100 -feet thick, and typically contains saline water. Altitude of the surface of the Saginaw aquifer ranges from 800 to 900 feet in the northern part of the aquifer system, and from 500 to 600 feet in the southern part. Altitude of the top of the Saginaw aquifer is lower in the western and eastern parts of the aquifer system (typically 400 to 500 feet). The Saginaw confining unit is thickest in the northwestern part of the aquifer system (100 to 240 feet thick); however, thickness decreases to 50 feet in the southeast. Thickness of the Parma-Bayport aquifer generally ranges from 100 to 150 feet. The surface configuration of this aquifer is similar in shape to the Saginaw aquifer; altitudes are highest in the southern and northern parts of the aquifer system (900 and 500 feet, respectively). Lowest altitude (approximately -100 feet) of the Parma-Bayport aquifer is in the east-central part of the basin. The Parma-Bayport aquifer contains freshwater in subcrop areas where it is in direct-hydraulic connection to permeable glacial deposits; however, this aquifer contains saline water or brine down dip from subcrop areas. 


\section{INTRODUCTION}

Mississippian through Jurassic bedrock units and unconsolidated Pleistocene glacial deposits form a regional system of aquifers and confining units in the central Lower Peninsula of Michigan. The areal extent of this aquifer system is approximately $22,000 \mathrm{mi}^{2}$ (fig. 1). This aquifer system was studied as part of the Regional Aquifer-System Analysis (RASA) program (Mandle, 1986; Mandle and Westjohn, 1989) of the U.S Geological Survey (USGS). The Michigan Basin RASA project is one of 28 USGS hydrogeologic investigations of regional aquifer systems of the United States (Weeks and Sun, 1987).

The purposes of this report are to describe the hydrogeology and hydraulic properties of Pennsylvanian and Mississippian bedrock units in the central Michigan Basin and to publish maps that delineate aquifer- and confining-unit boundaries. Descriptions of geologic units are summarized on the basis of published information and data collected as part of the Michigan Basin RASA investigation. Maps that delineate aquifer- and confining-unit boundaries were constructed by use of geophysical and geologic logs of oil, gas, and water wells.

\section{GEOLOGY}

The Michigan Basin is an intracratonic depression that contains more than $17,000 \mathrm{ft}$ of sedimentary rocks and unconsolidated sediments. The stratigraphic record is nearly complete from Precambrian sedimentary units through Jurassic red beds, with the exception that rocks of Triassic age are not present in the basin. Pleistocene glacial deposits cover bedrock in most areas, and knowledge of bedrock geology is almost entirely from geophysical and geologic logs of drill holes.

Geologic units that form the Michigan Basin regional aquifer system include units of Mississippian age and all younger geologic units. The aquifer system consists of six bedrock formations that have been assigned formal stratigraphic names and three geologic units that have informal names (figs. 2 and 3). Formally named units of Mississippian age are the Coldwater Shale, Marshall Sandstone, Michigan Formation, and Bayport Limestone; formally named units of Pennsylvanian age are the Saginaw Formation and Grand River Formation. Geologic units that have informal names are the Parma sandstone, Jurassic red beds, and Pleistocene glacial deposits. The stratigraphic relations of all units of the aquifer system are shown in figure 3 and in geologic sections A-A' and B-B' (Appen$\operatorname{dix}$ A).

The geology and hydrology of Mississippian rocks that form the lower part of the aquifer system and underlie the Bayport Limestone (Coldwater Shale, Marshall Sandstone, and Michigan Formation) are described in a report by Westjohn and Weaver (in press). Geologic units that form the upper part of the aquifer system (Jurassic red beds and Pleistocene glacial deposits) are described in a related USGS report (Westjohn and others, 1994). The geologic setting, stratigraphic relations, and hydrogeology of the Bayport Limestone, Parma Sandstone, Saginaw Formation, and Grand River Formation, which form the middle part of the regional aquifer system are described in this report.

2 Hydrogeologic Framework of Pennsylvanian and Late Mississippian

Rocks in the Central Lower Peninsula of Michigan 


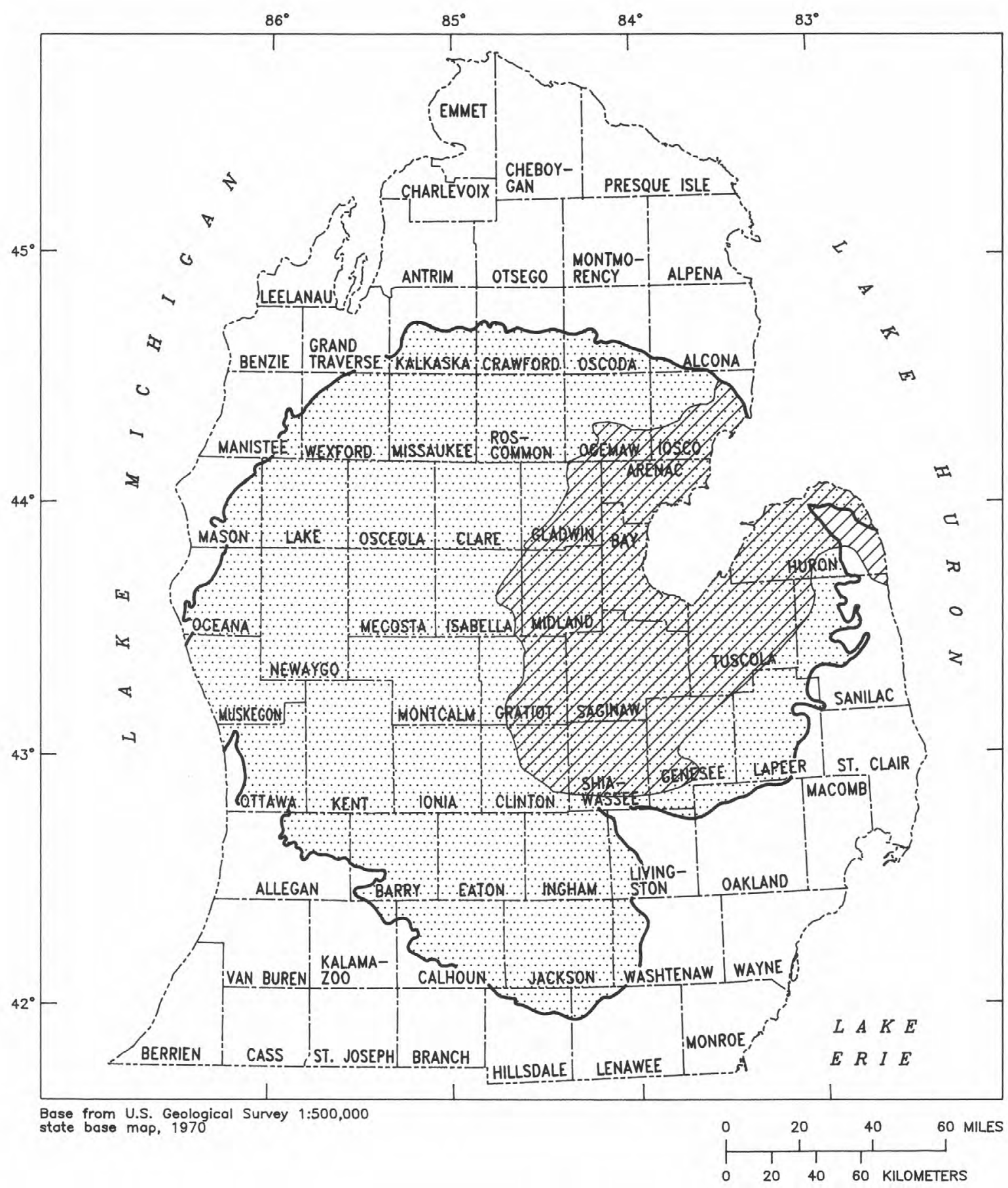

EXPLANATION

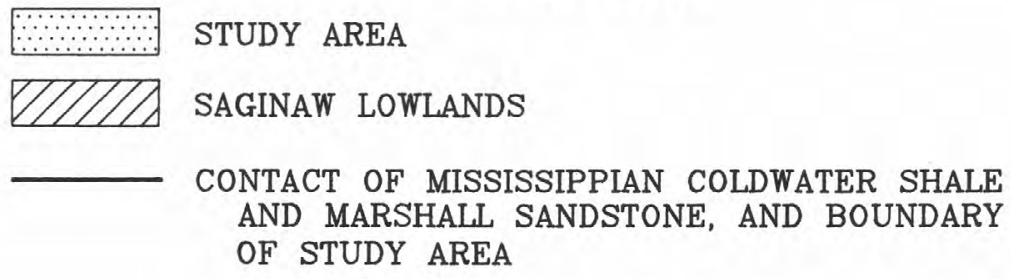

Figure 1. Lower Peninsula of Michigan and Michigan Basin Regional Aquifer-System Analysis study area. 


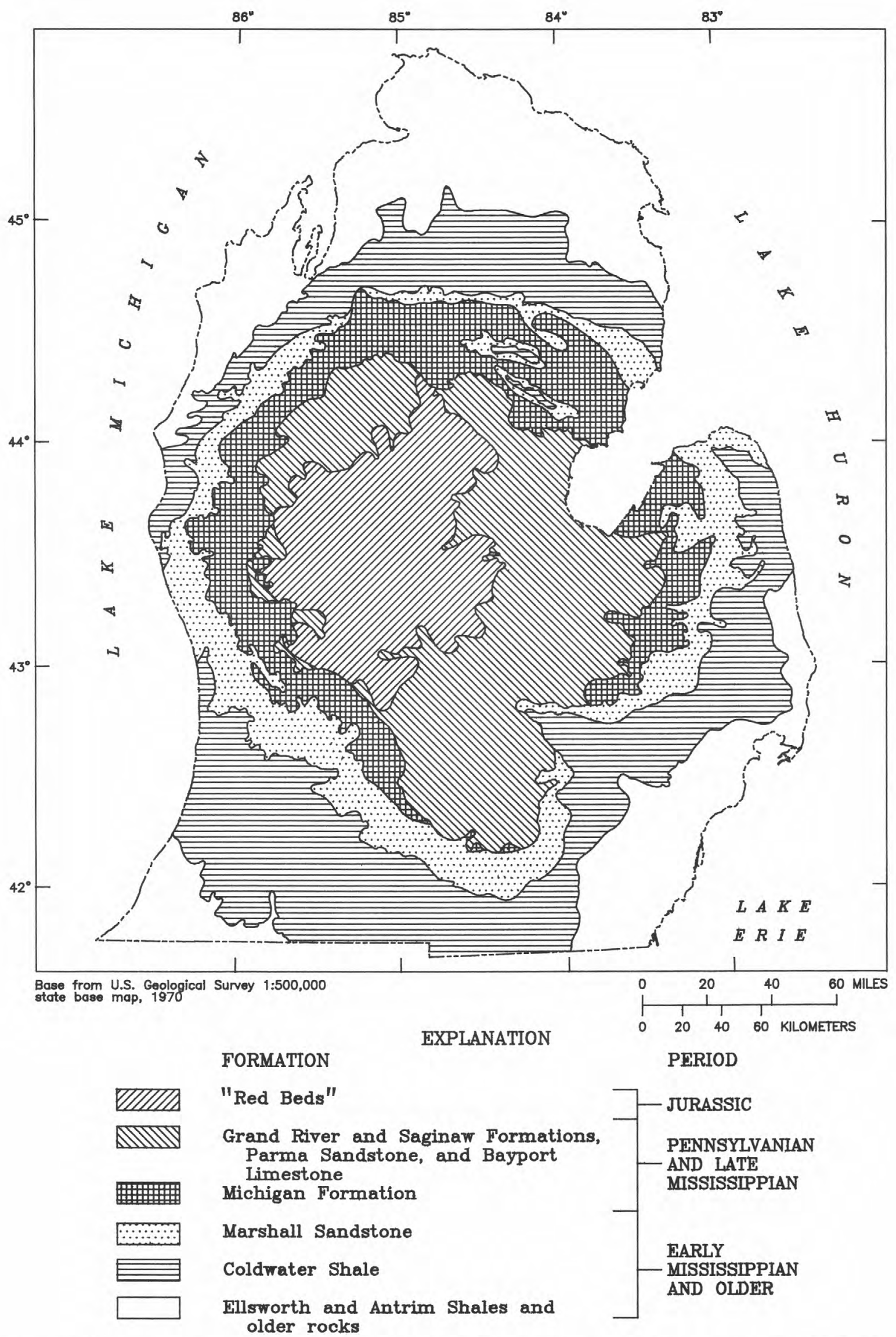

Figure 2. Bedrock geology of the Lower Peninsula of Michigan. (Modified from Western Michigan University, 1981, pl. 12; and from Westjohn and others, 1994.)

4 Hydrogeologic Framework of Pennsylvanian and Late Mississippian Rocks in the Central Lower Peninsula of Michigan 


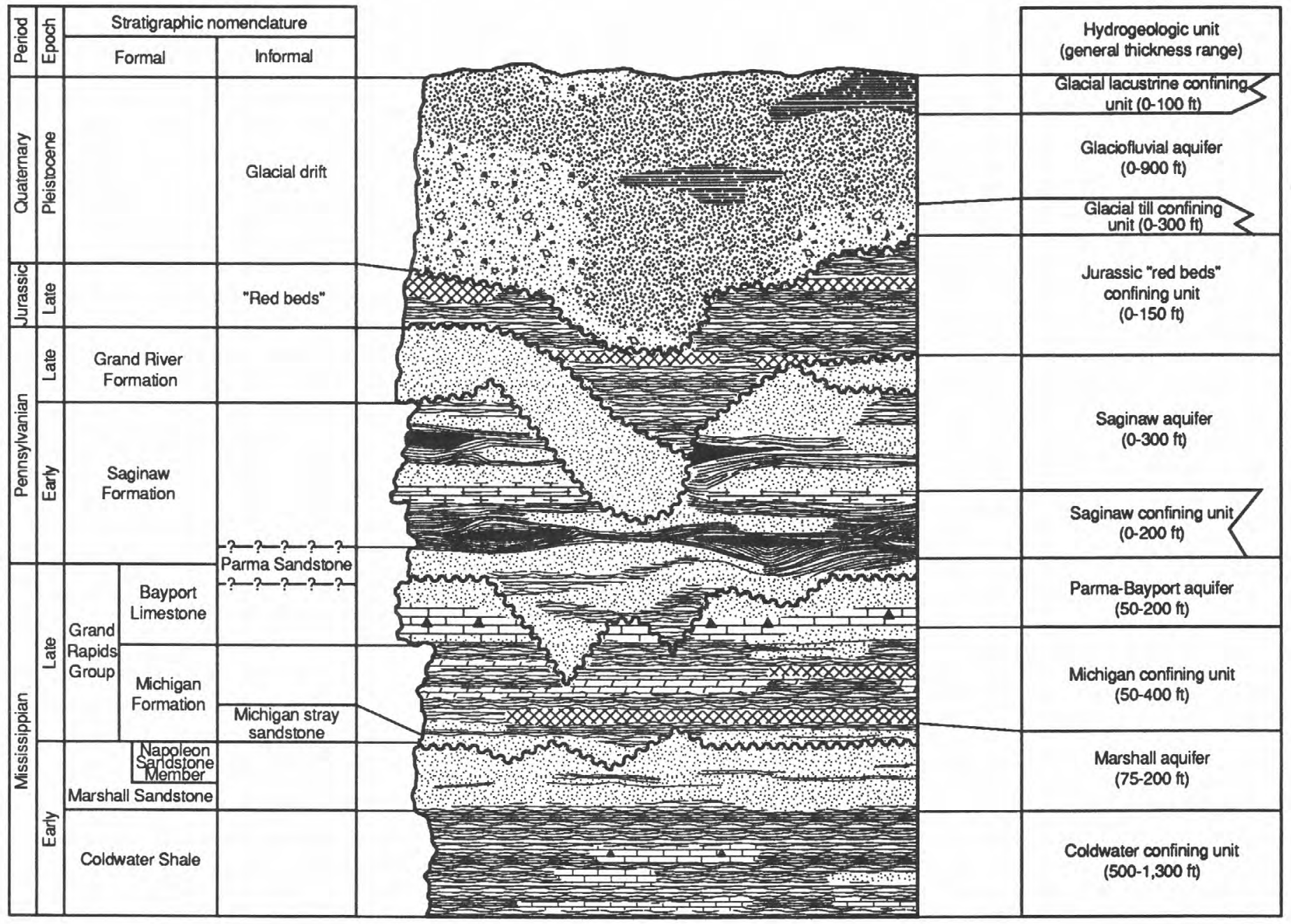

\section{EXPLANATION}

Glacial lacustrine sediments
Glacial till

Figure 3. Mississippian through Pleistocene stratigraphic nomenclature, hydrogeologic units, and rock units in the central Lower Peninsula of Michigan. (Modified from Michigan Geological Survey, 1964.) 


\section{Bayport Limestone}

The Mississippian Bayport Limestone consists of sparsely fossiliferous to very fossiliferous limestone, dolostone, sandy limestone, cherty limestone, and sandstone; thickness of the formation is typically 50 to $100 \mathrm{ft}$ (Cohee and others, 1951; Harrell and others, 1991). The Bayport Limestone is considered to form the upper part of the Grand Rapids Group (fig. 3), and this geologic unit overlies the Mississippian Michigan Formation (lower part of the Grand Rapids Group). Stratigraphic relations of the Bayport Limestone to other strata in the basin are shown in Lilienthal (1978), and are described by Cohee (1979), Ells (1979), and Newcombe (1933). The name "Bayport Formation" is often used informally, but Bayport Limestone, as originally named by Lane (1899), is the recognized formal stratigraphic name for this unit (Michigan Geological Survey, 1964, Chart 1). Most previous investigations that focused specifically on the Bayport Limestone are summarized in unpublished theses (Bacon, 1971; Ciner, 1988; Lasemi, 1975; Strutz, 1978; Tyler, 1980).

Geologic maps that illustrate the subcrop area of the Bayport Limestone were compiled by Martin (1936) and Milstein (1987). The major difference in these maps is that Martin (1936) shows the Bayport as stratigraphically discontinuous. The most recent map of bedrock geology (Milstein, 1987) illustrates the Bayport Limestone as a stratigraphically continuous unit. Geologic maps that predate Martin's map (1936) combine the Michigan Formation and Bayport Limestone and illustrate the areal extent of the Grand Rapids Group (Lane 1902a, 1905; Allen and others, 1916).

Structure-contour maps of the base of the Bayport Limestone were constructed by Lasemi (1975) and Strutz (1978). These investigators relied primarily on geologic logs; consequently, the maps are very similar. Vugrinovich (1984) relied substantially on geophysical logs to map a 5,500-mi2 area in the central part of the basin, and he compiled an isopach map and structure-contour map of the top of the Bayport Limestone. Tyler (1980) focused on a much smaller area (approximately $12 \mathrm{mi}^{2}$ ) and constructed structure-contour and isopach maps of different lithofacies trends that he interpreted from examinations of drill cuttings and from geophysical logs. Isopach maps generated by Cohee and others (1951) and Strutz (1978) illustrate similar thickness trends (typically 50 to $100 \mathrm{ft}$ ). Cohee and others (1951), however, interpreted the Bayport Limestone as being absent in many areas down dip from subcrop regions. Examination of geophysical logs by the authors of this report support interpretations of Cohee and others (1951) and Martin (1936) regarding the absence of Bayport Limestone in many areas of the basin.

\section{Parma Sandstone}

The Parma Sandstone consists of medium- to coarse-grained sandstone and is generally less than $100 \mathrm{ft}$ thick (Cohee and others, 1951). This geologic unit has not been the focus of any geologic investigation of the Michigan Basin, but it is mentioned in descriptions of Pennsylvanian rock units by several investigators (Cohee, 1965; Cohee and others, 1951; Dorr and Eschman, 1970, p. 349; Kelly, 1936; Wanless and Shideler, 1975; Winchell, 1861, p. 112). Several publications on Michigan Basin stratigraphy do not delineate the Parma Sandstone as a separate stratigraphic unit (Ells, 1979; Lane, 1902a; 1905; Milstein, 1987).

6 Hydrogeologic Framework of Pennsylvanian and Late Mississippian

Rocks in the Central Lower Peninsula of Michigan 
The Parma Sandstone is considered by many stratigraphers to form the basal part of the Pennsylvanian Saginaw Formation (Cohee and others, 1951; Kelly, 1936, p. 157; Wanless and Shideler, 1975). Nevertheless, the relations of this unit to recognized and formally named geologic strata are still subjects of debate. Vugrinovich (1984) used geophysical logs to map thickness of the Parma Sandstone in a region that makes up about one-half of the areal extent of this geologic unit (approximately $\left.5,500 \mathrm{mi}^{2}\right)$. Vugrinovich $(1984$, p. 9) did a detailed stratigraphic and lithologic investigation of Late Mississippian and Pennsylvanian rocks in the Michigan Basin, and he suggests that "the name Parma should be raised again to formational rank to designate the sequence of sandstones immediately overlying the Bayport Limestone." Vugrinovich (1984) also suggests, on the basis of stratigraphic relations, that the lower part of the Parma Sandstone should be assigned to the Late Mississippian; however, assignment of Early Pennsylvanian or Late Mississippian to the Parma Sandstone is conjectural, because indicator fossils that would provide a means to establish age are absent.

Geologic maps that illustrate the subcrop area of the Parma Sandstone were published as part of early investigations (Martin, 1936; Winchell, 1869). Some subsurface geologic maps combine the Parma Sandstone with other geological units (Allen and others, 1916; Lane, 1899, 1902a, 1905; Martin and Straight, 1956), and the most recently published bedrock geologic map of Michigan does not show the Parma Sandstone at all (Milstein, 1987).

A search of geologic literature failed to locate maps that show surface configuration or thickness of Parma Sandstone over the entire areal extent of this geologic unit.

\section{Saginaw and Grand River Formations}

Pennsylvanian rocks in the Michigan Basin have been formally subdivided into the Saginaw Formation (Early Pennsylvanian) and Grand River Formation (Late Pennsylvanian) (fig. 3). The Saginaw Formation constitutes the bulk of the Pennsylvanian rock sequence and consists of interbedded sandstone, siltstone, shale, coal, and limestone.

Previous investigations of Pennsylvanian rocks in Michigan focused almost entirely on geological aspects including stratigraphy (Kelly, 1936; Shideler, 1969; Vugrinovich, 1984; Wanless and Shideler, 1975), coal resources (Cohee and others, 1950; Lane, 1900; 1902b), depositional setting (Martin, 1982; Strutz, 1978; Tyler, 1980), and sedimentology (Cohee and others, 1951; Ells, 1979; Velbel and Brandt, 1989). Studies related to the hydrogeology of Pennsylvanian rocks include a compilation of ground-water-resource information (Western Michigan University, 1981), a waterresources investigation of a three-county area (Vanlier and others, 1973), and a regional hydrogeologic investigation and simulation of ground-water flow (Mandle and Westjohn, 1989).

A map showing the total thickness of Pennsylvanian rocks was published by Strutz (1978). Shideler (1969) subdivided Pennsylvanian rocks by time-stratigraphic series (North American provincial series) and generated maps showing the composite thickness of sandstones of the Desmoinesian, Atokan, and Morrowan subdivisions. The isolith maps of Shideler (1969) illustrate restored and exaggerated thickness rather than actual thickness, and were prepared for use as an aid to interpret dispersal patterns of Pennsylvanian sediments. Maps that delineate aquifer- and confining-unit boundaries within the Pennsylvanian rock sequence were not located during the literature search of this study. 


\section{Location and Extent}

The Grand River Formation is the stratigraphic name attributed to Kelly (originally Grand River Group, see Kelly, 1936, p. 206) for Pennsylvanian rocks exposed along the Grand River in northcentral Eaton County (fig. 1). The Grand River Formation is reported to consist predominantly of sandstone, although Kelly (1936, p. 209) said that a conglomerate bed at the type locality (northcentral Eaton County) separates the Grand River Formation from the underlying Saginaw Formation. The authors of this report examined more than 12,000 geologic logs of boreholes drilled through the entire Pennsylvanian rock sequence and found that conglomerate seems to be rare and highly localized. It is difficult, if not impossible, to assign sandstones or other Pennsylvanian rocks to either the Saginaw Formation or the Grand River Formation with any degree of certainty because no lithologic differences or stratigraphic horizons mark a change from one formation to the next.

The most recent bedrock geologic map of Michigan (Milstein, 1987) shows the areal extent of the Grand River Formation to be small (less than $350 \mathrm{mi}^{2}$ ) in comparison to the areal extent of the Saginaw Formation (larger than $11,000 \mathrm{mi}^{2}$ ). The Grand River Formation is not considered to be an important rock unit in the RASA study area because of its small extent. All further discussion of Pennsylvanian rocks above the Parma Sandstone is therefore limited to the Saginaw Formation.

\section{Relations of Stratigraphic Units to Aquifer and Confining Units}

Relations of commonly used stratigraphic names to hydrogeologic nomenclature established for the Michigan Basin RASA study are shown in figure 3. Also shown are lithologic constituents of formations and thicknesses of aquifer and confining units. The boundaries and thicknesses of aquifers and confining units of the Michigan Basin regional aquifer system were delineated on the basis of hydraulic properties. Thus a hydrogeologic unit might include all or part of a formation, depending on hydraulic properties of strata within a formation. For example, the Parma Sandstone and Bayport Limestone, which are hydraulically connected and consist primarily of permeable lithologies, together form the Parma-Bayport aquifer (fig. 3). In contrast, the terms Mississippian Coldwater Shale (formal stratigraphic nomenclature) and Coldwater confining unit (hydrogeologic name) refer to the same geologic unit (fig. 3). Stratigraphic names and hydrogeologic-unit nomenclature are used alternately in this report, depending on whether the topic of discussion is geology or hydrogeology. The terms Mississippian sandstone and Pennsylvanian sandstone are used in a general sense where association of rock units to a specific formation is not critical.

\section{DELINEATION OF AQUIFER- AND CONFINING-UNIT BOUNDARIES}

Several of the units that form the aquifer system have been the subject of detailed geologic studies, and maps that were generated as part of these investigations were prepared to aid in the interpretation of stratigraphy, sedimentology, and depositional environment (Allen and others, 1916; Cohee and others, 1951; Lane, 1902a, 1905; Lasemi, 1975; Martin, 1936; Martin and Straight, 1956; Milstein, 1987; Strutz, 1978; Tyler, 1980; Vugrinovich, 1984; Wanless and Shideler, 1975; Winchell, 1869). The thickness and surface-configuration maps in this report delineate aquifer and confining-unit boundaries rather than contacts of different formations. These maps were prepared to assist in computer simulation of ground-water flow.

8 Hydrogeologic Framework of Penneylvanian and Late Miseiseippian

Rocks in the Central Lower Peninsula of Michigan 
Geophysical logs of oil and gas wells were used to establish hydrogeologic characteristics and to map hydrostratigraphic units in the central part of the basin. In areas where geophysical logs are sparse or unavailable, delineation of aquifer and confining-unit boundaries was based on data recorded in geologic logs of oil, gas, and water wells. Interpretation of geophysical logs is the primary basis for delineation of hydrostratigraphic units of the Michigan Basin regional aquifer system. In Appendix B, example logs are provided, and methods used to delineate aquifer and confining-unit boundaries by interpretation of geophysical and geologic logs are described.

\section{HYDROGEOLOGY}

Pennsylvanian rocks that overlie the Parma Sandstone consist of complexly intercalated aquifer and confining-unit material. Thickness of Pennsylvanian rocks (above the Parma Sandstone) typically ranges from approximately 100 to $500 \mathrm{ft}$ and exceeds $600 \mathrm{ft}$ in the north-central part of the aquifer system (fig. 4). Relief on the surface of Pennsylvanian rocks is approximately $600 \mathrm{ft}$. Altitude ranges from approximately $350 \mathrm{ft}$ in the west-central to east-central parts of the subcrop area to highs of $600 \mathrm{ft}$ in the north and $900 \mathrm{ft}$ in the south (fig. 5). The locations of boreholes whose geologic logs were used to construct thickness and surface-configuration maps are shown in Appendix C.

In Michigan, vertical sequences of sedimentary strata can be identified, which are similar to the cyclothem series that is considered generally to be characteristic of Pennsylvanian sedimentary sequences in other areas of the United States (Weller, 1930). However, all lithologies typical of such rock sequences are stratigraphically discontinuous at the scale of the RASA study area. In most areas of the Michigan Basin, individual Pennsylvanian strata above the Parma Sandstone cannot be traced laterally more than a few miles. The complex stratigraphic relations and lateral discontinuity of different lithologies complicates delineation of aquifer- and confining-unit boundaries at the scale of the study area.

Interpretation of geophysical logs indicates that the lower part of the Pennsylvanian rock sequence is predominantly shale, whereas the upper part is predominantly sandstone. Subdivision of Pennsylvanian rocks younger than the Parma Sandstone into a lower confining unit (Saginaw confining unit, see fig. 3) and an upper sandstone aquifer (Saginaw aquifer) was determined to be the most suitable approach for the Michigan Basin RASA's computer simulation of ground-water flow.

The Bayport Limestone and Parma Sandstone appear to interfinger throughout the Michigan Basin. These units are stratigraphically continuous and hydraulically connected, and together they form the Parma-Bayport aquifer. The hydrogeologic characteristics of the Saginaw aquifer, Saginaw confining unit, and Parma-Bayport aquifer are discussed separately in the following sections of this report.

\section{Saginaw Aquifer}

The Saginaw aquifer is the cumulative thickness of sandstones that overlie the Saginaw confining unit (fig. 3). These sandstones are assumed to be hydraulically connected at the scale of the study area; therefore they form a regional aquifer that functions as a single layer for computer simulation of ground-water flow (N.G. Grannemann, U.S. Geological Survey, oral commun., 1992). 


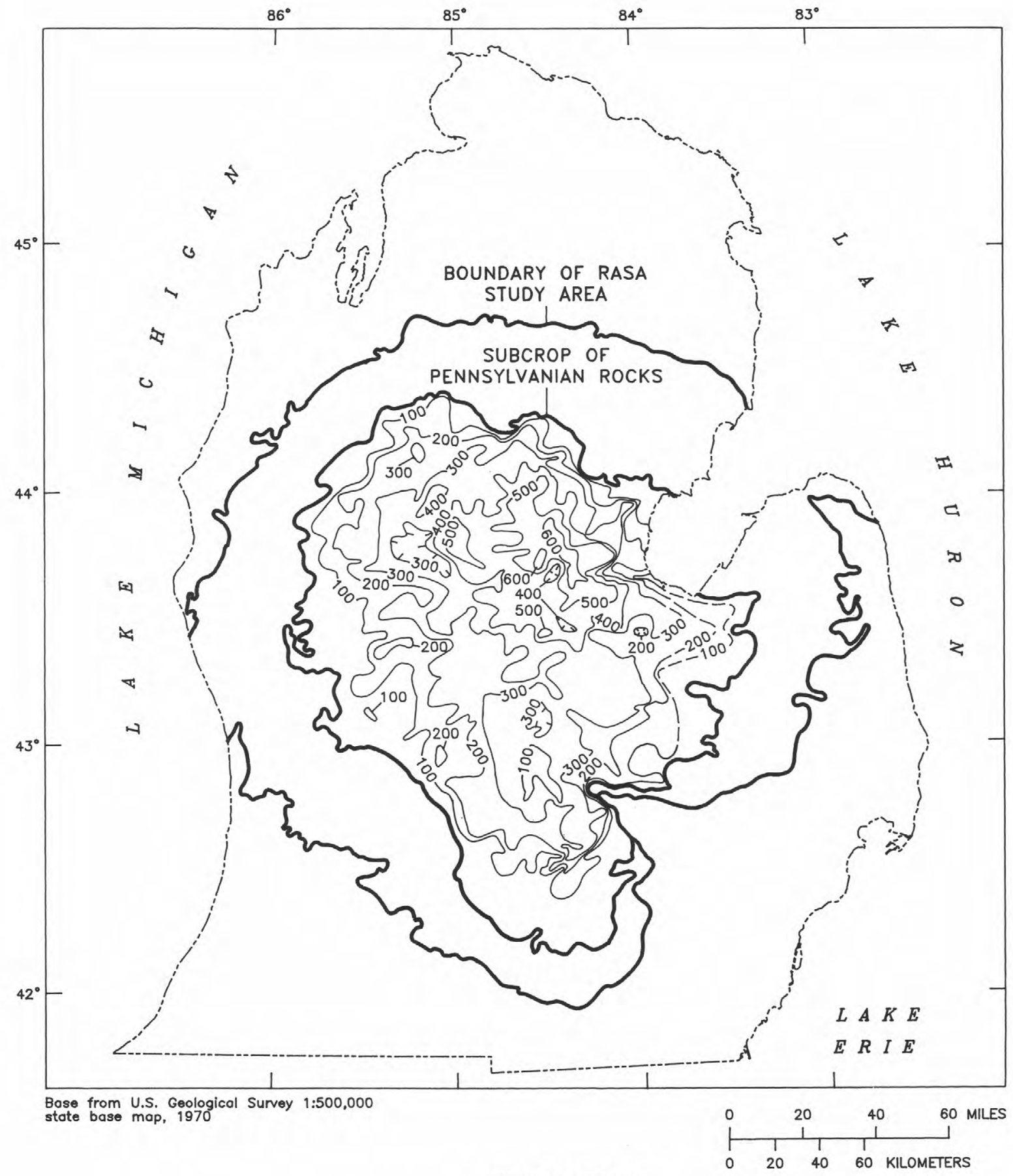

EXPLANATION

-100-- LINE OF EQUAL THICKNESS OF BEDROCK--Shows

thickness of Pennsylvanian rocks. Dashed

where approximately located. Hachures

indicate depression. Contour interval

100 feet. Datum is sea level

Figure 4. Thickness of Pennsylvanian rocks in the central Lower Peninsula of Michigan.

10 Hydrogeologic Framework of Pennsylvanian and Late Mississippian

Rocks in the Central Lower Peninsula of Michigan 


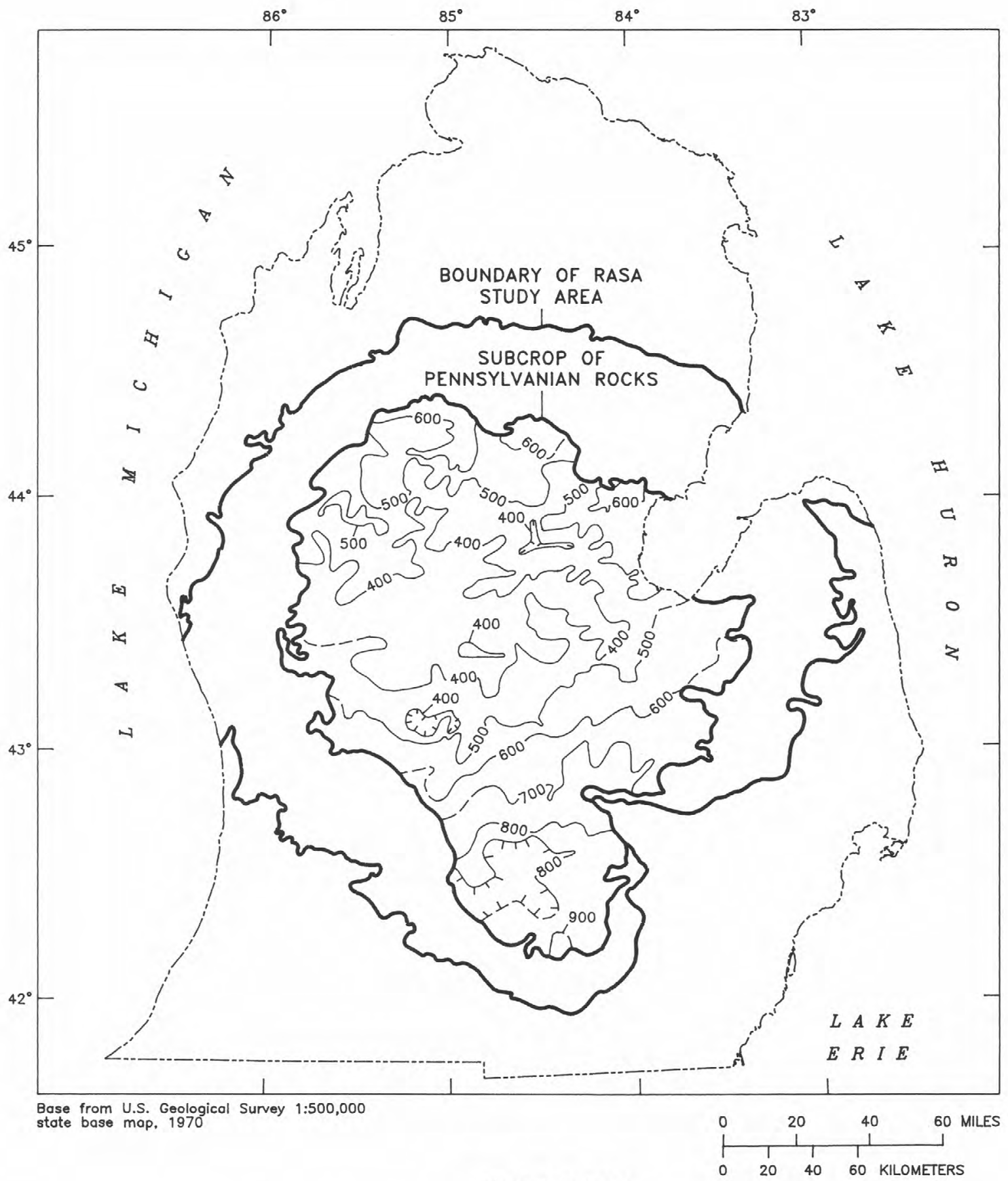

EXPLANATION

-900--- STRUCTURE CONTOUR--Shows altitude of top of Pennsylvanian rocks. Dashed where approximately located. Hachures indicate depression. Contour interval 100 feet. Datum is sea level

Figure 5. Surface configuration of Pennsylvanian rocks in the central Lower Peninsula of Michigan. 
The areal extent of the Saginaw aquifer is approximately $11,000 \mathrm{mi}^{2}$. The aquifer is thin (less that $100 \mathrm{ft}$ thick) near the boundary of the study area (fig. 6). The Saginaw aquifer is thickest along a 30- to 45-mi-wide south-trending corridor through the approximate center of the study area, where thickness ranges from 100 to $370 \mathrm{ft}$ (fig. 6). The Saginaw aquifer constitutes the upper part of the Pennsylvanian rock sequence, and the configuration of the surface of the Saginaw aquifer is the same as illustrated for the Pennsylvanian rock sequence (fig. 5). The locations of drill holes whose geologic logs were used to construct surface-configuration and thickness maps of the Saginaw aquifer are shown in Appendix C.

\section{Hydraulic Properties}

Analyses of aquifer-test data indicate a wide range of transmissivities within the Saginaw aquifer. Transmissivities that range from 130 to $2,700 \mathrm{ft}^{2} / \mathrm{d}$ were reported for a three-county area (fig. 1, Clinton, Eaton, and Ingham Counties) by Vanlier and Wheeler (1968), where the Saginaw aquifer is the principal source of water for municipal supply.

Measurements of matrix-controlled hydraulic properties were made of a suite of sandstone samples (Saginaw Formation). Measured porosities and matrix-controlled vertical hydraulic conductivities range from 4 to 34 percent and 0.0001 to $55 \mathrm{ft} / \mathrm{d}$, respectively. These large ranges of porosities and hydraulic conductivities generally are a function of cement type and degree of cementation. A complete tabulation of the hydraulic-property data can be found in a report by Westjohn and others (1990).

\section{Use and Quality of Water}

The Saginaw aquifer is a source of water for numerous residential wells (Western Michigan University, 1981, pl. 20), and for at least 32 municipalities (Baltusis and others, 1992). All municipalities that use ground water from the Saginaw aquifer are located in the eastern part of the study area. The Saginaw aquifer generally is productive and freshwater bearing along the south-trending corridor where sandstones are thick (fig. 6). Most municipalities that use ground water from the aquifer are located along this freshwater-bearing bedrock corridor.

In the Lansing area, ground-water withdrawal from the Saginaw aquifer exceeds $30 \mathrm{Mgal} / \mathrm{d}$, which is the largest withdrawal rate of ground water from a bedrock source in Michigan (Baltusis and others, 1992). Areas where the Saginaw aquifer is freshwater bearing also appear to be in directhydraulic connection with Pleistocene glaciofluvial deposits (Westjohn, 1993; Westjohn, 1994; Westjohn and others, 1994).

In the west-central part of the aquifer system, Jurassic red beds separate the Saginaw aquifer from glacial deposits; here the Saginaw aquifer typically contains saline water. Jurassic red beds form a sub-regional confining unit (figs. 2 and 3), and seem to impede recharge of freshwater from overlying glacial deposits (Westjohn and others, 1994). Saline water is also present in the Saginaw aquifer in the east-central part of the study area (Saginaw Lowlands, fig. 1), where fine-grained lacustrine sediments and clay-rich-lodgment tills are the dominant types of glacial material. The 

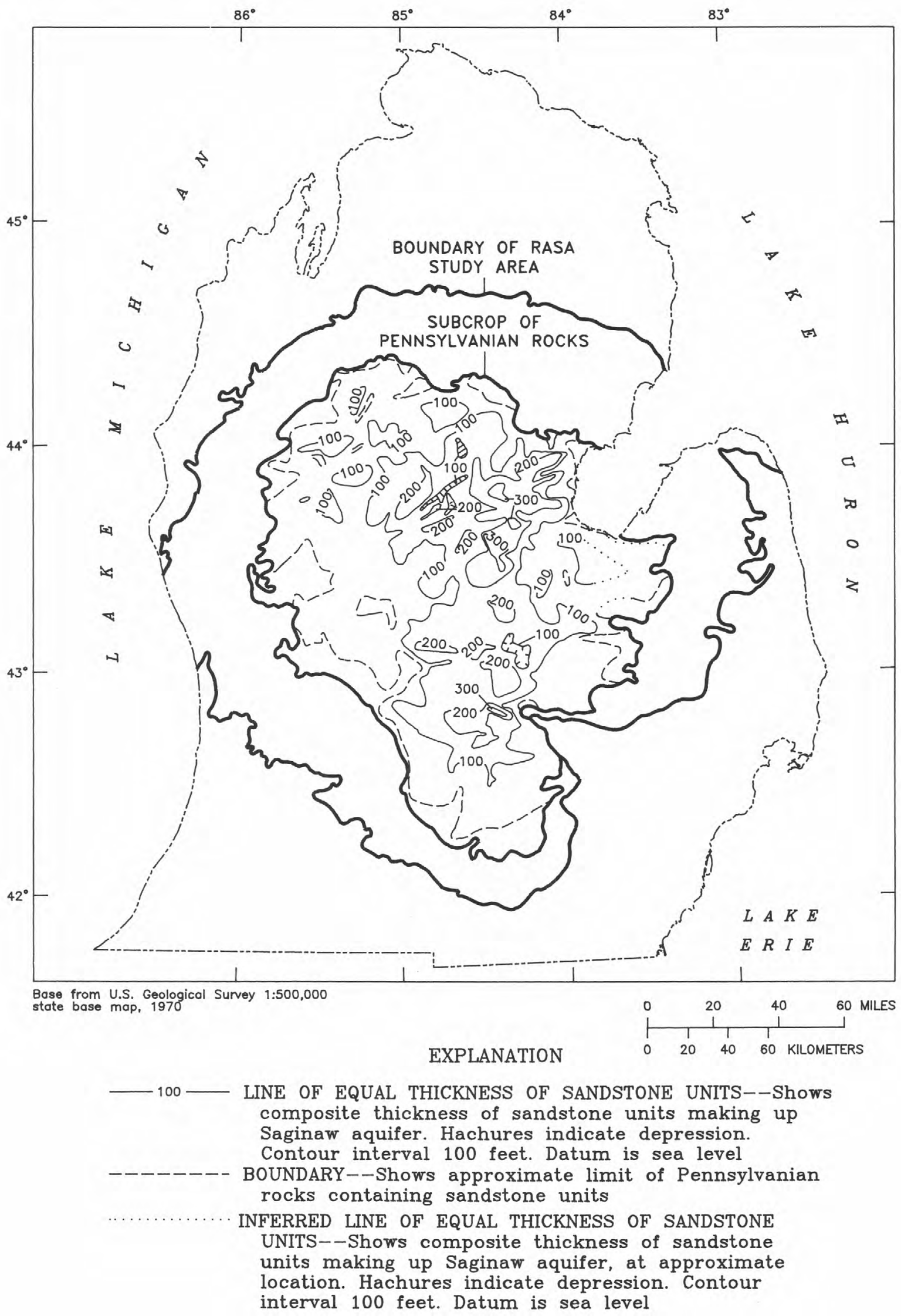

Figure 6. Thickness of Saginaw aquifer in the central Lower Peninsula of Michigan. 
lacustrine sediments and clay-rich-lodgment tills appear to trap and (or) inhibit discharge of ground water in this area (Westjohn, 1993).

\section{Saginaw Confining Unit}

The Saginaw confining unit is present in most of the study area and separates the Saginaw aquifer from the underlying Parma-Bayport aquifer (fig. 3). This confining unit consists predominantly of shale; the rest of the sequence consists of sandstone, siltstone, coal, and limestone beds. Geophysical logs show that sandstone and siltstone beds typically are thin (less than $15 \mathrm{ft}$ ) and discontinuous, and generally cannot be traced laterally more than 5 to $10 \mathrm{mi}$. Electric logs show that sandstone and siltstone beds within this predominantly Pennsylvanian shale sequence contain saline water or brine (Westjohn, 1989); these permeable strata are assumed to be isolated from the regional ground-water-flow system.

\section{Areal Extent and Thickness}

The Saginaw confining unit has the same areal extent as the Saginaw aquifer (approximately $11,000 \mathrm{mi}^{2}$ ). The thickness of this confining unit ranges from 100 to $240 \mathrm{ft}$ in the northwest, but decreases to approximately $50 \mathrm{ft}$ near the boundary of the study area (fig. 7). Thickness of the Saginaw confining unit was delineated entirely on the basis of interpretation of geophysical logs (Appendix C).

In the central part of the study area, where the confining unit is thickest, lithology and thickness were delineated by use of electrical-resistivity and spontaneous-potential logs, which were run in boreholes open to Pennsylvanian rock units. The thickness of the Saginaw confining unit is poorly constrained in the central and southeastern parts of the study area because geophysical logs for this area are few in number and uneven in distribution.

Use and Quality of Water

Water wells are rarely completed in bedrock in the northeastern part of the study area, because overlying glacial deposits are a shallow source of ground water (Westjohn and others, 1994). Water quality is interpreted from electrical-resistivity logs of oil and gas wells (Westjohn, 1989). Thinsandstone beds are commonly intercalated with shale. The sandstone beds contain saline water or brine, and the salinity of ground water increases with depth. The quality of ground water in the Saginaw confining unit in other areas of the Michigan Basin is unknown.

\section{Parma-Bayport Aquifer}

The Parma Sandstone and Bayport Limestone are considered by most geologists to be separate and distinct time-stratigraphic units. Examination of geophysical logs shows that these units consist mostly of permeable sandstones and carbonates and that the formations are hydraulically connected throughout the area of the regional aquifer system. For characterization of hydrogeologic setting and computer simulation of ground-water flow, these units are combined to form the Parma-Bayport aquifer.

14 Hydrogeologic Framework of Pennsylvanian and Late Mississippian

Rocks in the Central Lower Peninsula of Michigan 


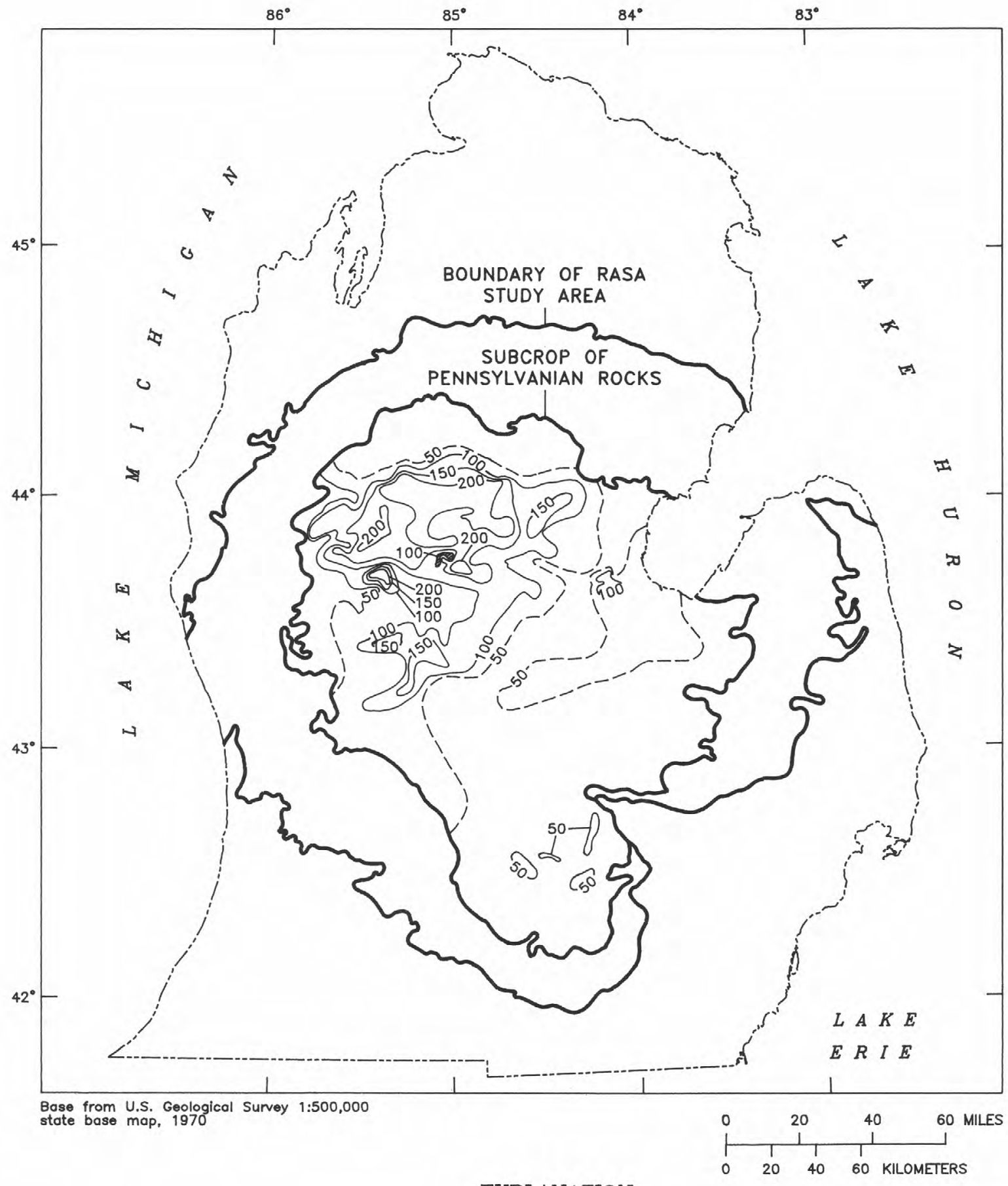

EXPLANATION

-50--- LINE OF EQUAL THICKNESS OF SHALE--Shows

thickness of Saginaw confining unit. Dashed where approximately located. Hachures indicate depression. Contour interval 50 feet. Datum is sea level

Figure 7. Thickness of Saginaw confining unit in the central Lower Peninsula of Michigan. 
The areal extent of the Parma-Bayport aquifer is approximately $11,000 \mathrm{mi}^{2}$. Thickness of this aquifer exceeds $200 \mathrm{ft}$ in some parts of the area mapped (fig. 8); in most areas, however, thickness generally ranges from 100 to $150 \mathrm{ft}$. Relief on the surface of the Parma-Bayport aquifer is approximately $1,000 \mathrm{ft}$ (fig. 9). Altitudes are lowest (approximately $100 \mathrm{ft}$ below sea level) in the eastcentral part of the study area and highest in the south and north (approximately 900 and $500 \mathrm{ft}$, respectively). The locations of boreholes whose geophysical and geologic logs were used to construct maps of the Parma-Bayport aquifer are shown in Appendix C.

In the northeastern part of the aquifer system, the Parma-Bayport aquifer was delineated primarily on the basis of characteristic electric-log traces (Appendix C). Electric logs typically display mud-invasion profiles, indicating the bulk of this aquifer is permeable (Appendix B). Gamma-ray logs were used to delineate boundaries of the aquifer in the southeast (Appendix C). Data recorded in geologic logs were necessary to complete the thickness and surface-configuration maps in several areas where no geophysical logs are available (Appendix C).

\section{Hydraulic Properties}

Geophysical logs run in boreholes open to the Parma-Bayport aquifer are the basis for the description of general hydrologic characteristics. In the central part of the basin, highly permeable sandstone (approximately $100 \mathrm{ft}$ thick) is the predominant lithology. Evidence of the high permeability of this sandstone is indicated by caliper and porosity logs. Caliper logs show that borehole diameter is larger than bit diameter by several inches in upper part of the sandstone sequence. This indicates that fluid circulation during drilling eroded poorly consolidated, permeable sandstone. Geophysical logs show that porosities in the upper part of the sandstone sequence typically range from 25 to 35 percent; these are the highest porosities of any bedrock unit in the aquifer system (Westjohn and others, 1990). Porosity decreases and sandstones become more consolidated with depth. Below the predominantly sandstone part of the Parma-Bayport aquifer, the unit consists of calcareous or dolomitic sandstone, limestone, dolomite, and shale. Lithologies below the permeable sandstone are complexly intercalated, and the composite thickness is usually less than $\mathbf{5 0} \mathrm{ft}$.

Hydraulic-property data for the Parma-Bayport aquifer are scanty, primarily because this aquifer is rarely used for water supply. No records of aquifer tests are known, but helium-gas measurements of hydraulic properties were made of a suite of Parma Sandstone cores to evaluate gas-storagereservoir properties (Robert Bomar, Michigan Consolidated Gas Company, written commun., 1993). Data reported from these tests are in millidarcies, the standard units used by the oil and gas industry. These units, rather than hydraulic conductivity, are retained to indicate that permeability was measured.

Vertical and horizontal permeability components and porosity were measured of 106 core specimens. Vertical and horizontal permeability components have approximately the same range ( 0.1 to 2,500 millidarcies), and porosity ranges from 2 to 25 percent. These ranges are similar to those reported for the Pennsylvanian sandstones that overlie the Parma-Bayport aquifer (Westjohn and others, 1990).

16 Hydrogeologic Framework of Pennsylvanian and Late Mississippian Rocks in the Central Lower Peninsula of Michigan 


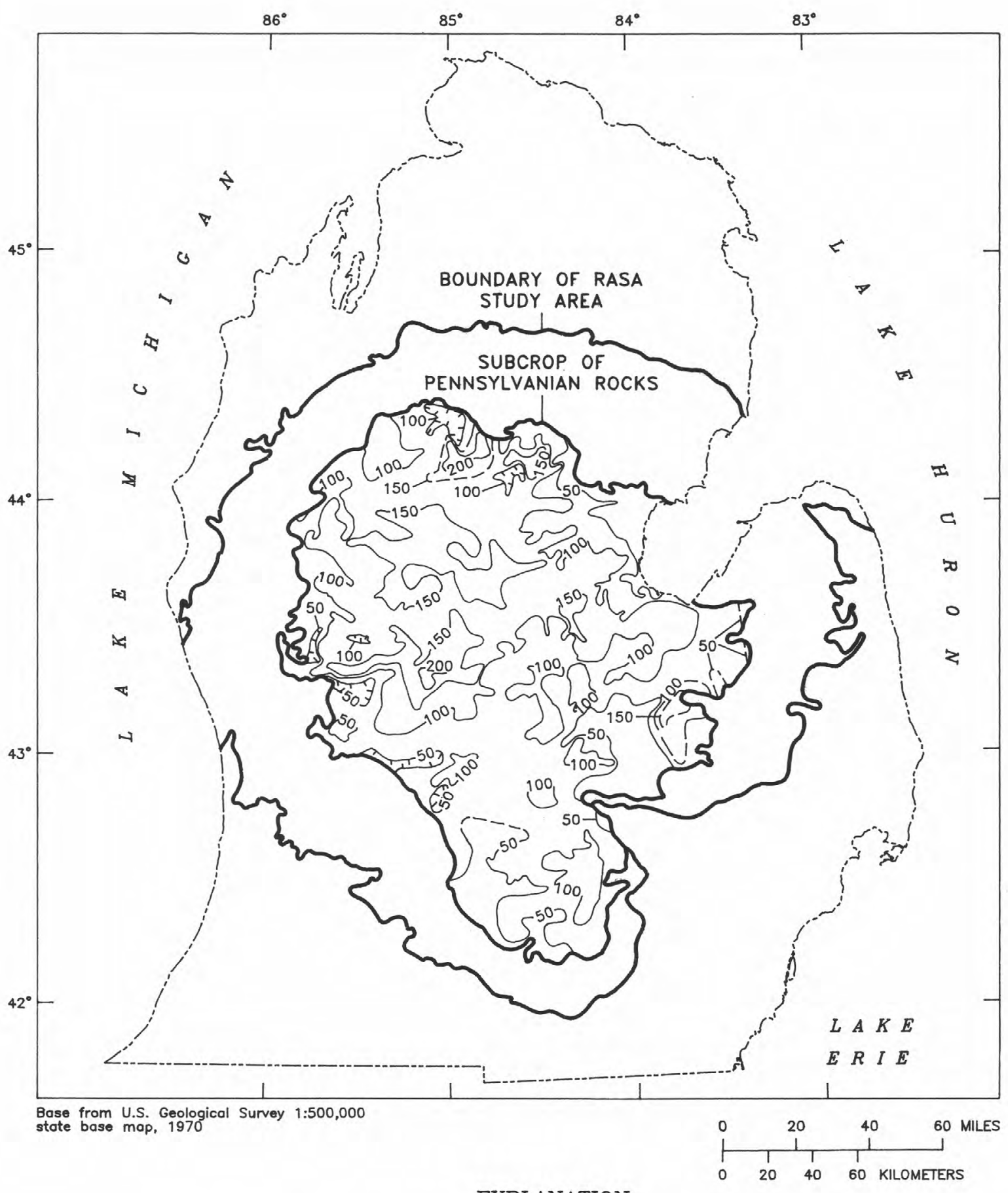

EXPLANATION

- 50--- LINE OF EQUAL THICKNESS OF BEDROCK--Shows

thickness of Parma-Bayport aquifer. Dashed where approximately located. Hachures

indicate depression. Contour interval

50 feet. Datum is sea level

Figure 8. Thickness of Parma-Bayport aquifer in the central Lower Peninsula of Michigan. 


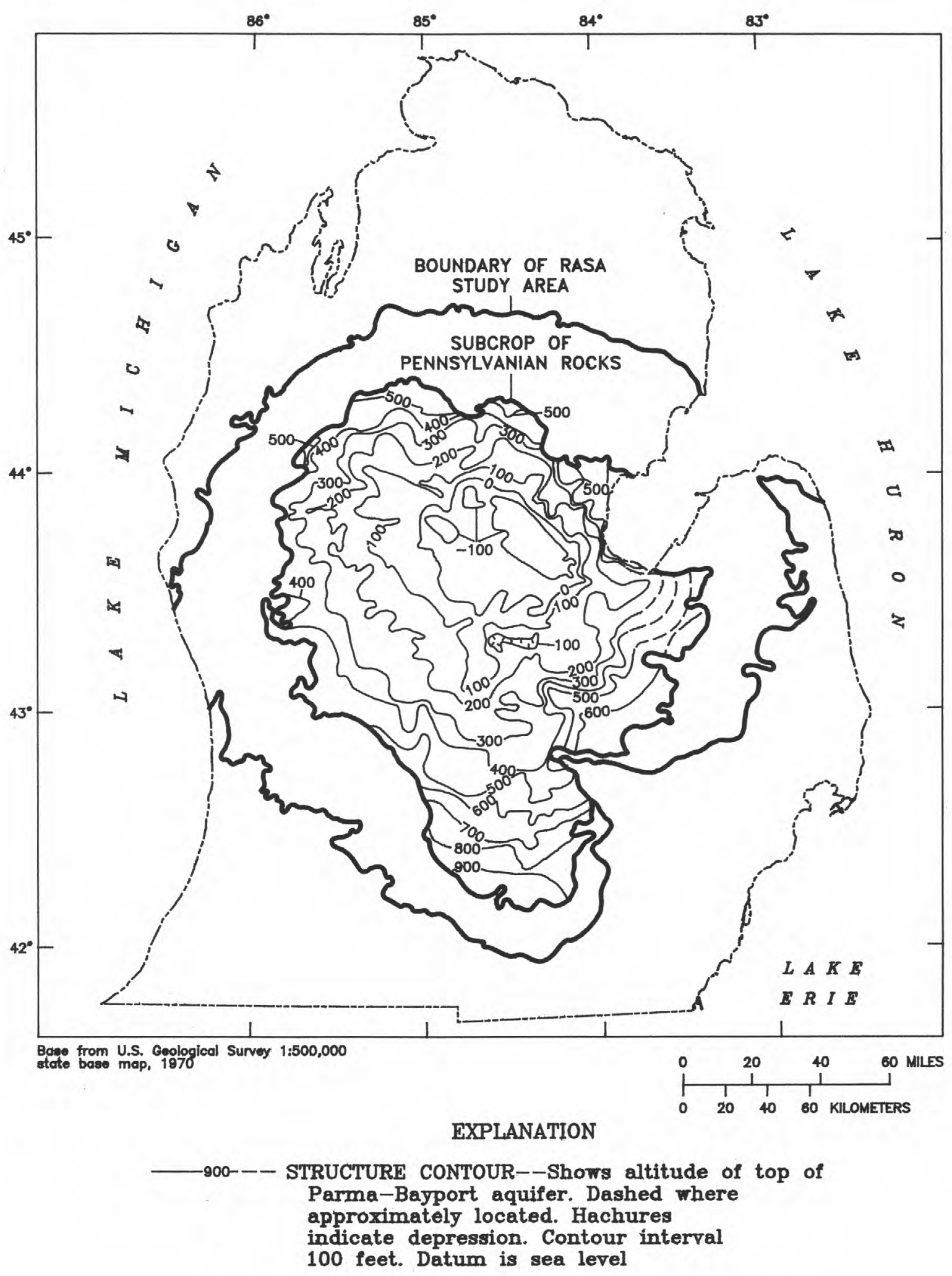

Figure 9. Surface configuration of Parma-Bayport aquifer in the central Lower Peninsula of Michigan.

18 Hydrogeologic Framework of Pennsylvanian and Late Mississippian

Rocks in the Central Lower Peninsula of Michigan 
Examination of core specimens indicates that permeability and porosity vary as a function of degree of cementation. Cements in the Parma-Bayport aquifer are the same as those determined for the Saginaw aquifer (Westjohn and others, 1991).

\section{Use and Quality of Water}

The Parma-Bayport aquifer is a source of domestic water supply in some areas of the basin. At least two municipalities use ground water from this source (Dannemiller and Baltusis, 1990).

In most areas of the basin, the Parma-Bayport aquifer contains saline water or brine. Electricalresistivity logs have been interpreted to show that freshwater is present only in areas where the aquifer is in direct hydraulic connection to overlying Pleistocene glacial deposits (Westjohn, 1989, 1993, 1994). The transition from freshwater to brine takes place over a distance less than $10 \mathrm{mi}$ down regional dip and away from subcrop areas in the northern part of the aquifer system. The transition zone of freshwater to brine is much broader in the southern part of the aquifer system (greater than $20 \mathrm{mi}$ ). Water-quality data for ground water from deepest parts of the Parma-Bayport aquifer (greater than $800 \mathrm{ft}$ deep) show that dissolved-solids concentration exceeds $200,000 \mathrm{mg} / \mathrm{L}$ (Western Michigan University, 1981, pl. 23; Michigan Department of Public Health water-quality records). Such a concentration is consistent with the interpretation of geophysical-log data (Westjohn, 1989, 1993, 1994).

\section{SUMMARY}

Late Mississippian and Pennsylvanian sedimentary rocks form part of a regional system of aquifers and confining units in the central Lower Peninsula of Michigan. The upper part of the Pennsylvanian rock sequence constitutes the Saginaw aquifer, which is primarily sandstone. This sandstone aquifer is a source of water for domestic use and for many municipalities. Production from the Saginaw aquifer in the Lansing area exceeds $30 \mathrm{Mgal} / \mathrm{d}$, which is the largest withdrawal rate of ground water from a bedrock source in Michigan. The Saginaw aquifer overlies the Saginaw confining unit, which consists primarily of shale. The Saginaw confining unit separates the Saginaw aquifer from the Parma-Bayport aquifer, which consists primarily of permeable sandstones and carbonates that are hydraulically connected and stratigraphically continuous. The Parma-Bayport aquifer contains freshwater only in areas where it is in direct-hydraulic connection to overlying Pleistocene glacial deposits. Down regional dip and away from subcrop areas, the Parma-Bayport aquifer contains saline water or brine.

Geophysical and geologic logs were used to construct thickness and surface-configuration maps of aquifer and confining units. The Saginaw aquifer ranges in thickness from 100 to $370 \mathrm{ft}$ along a 30- to 45-mi-wide south-trending corridor through the approximate center of the aquifer system. This trend of thick sandstone approximately delineates the area where the Saginaw aquifer is freshwater bearing. On either side of the south-trending corridor, the Saginaw aquifer generally contains saline water. The Saginaw confining unit is thickest in the northwestern part of the aquifer system (100 to $240 \mathrm{ft}$ thick); however, its thickness decreases to $50 \mathrm{ft}$ in the southeast. The Parma-Bayport aquifer typically ranges in thickness from 100 to $150 \mathrm{ft}$. 
Thickness and surface-configuration maps were prepared to aid in the assessment of hydrogeologic and geochemical characteristics of the regional aquifer system, and these maps delineate aquifer- and confining-unit boundaries for purposes of computer simulation of ground-water flow.

\section{REFERENCES CITED}

Allen, R.C., Smith, R.A., and Barrett, L.P., 1916, Geological map of Michigan: Michigan Geological and Biological Survey, Publication 23, Geological Series 19, scale 1:750,000.

Bacon, D.J., 1971, Chert genesis in a Mississippian sabkha environment: East Lansing, Mich., Michigan State University, M.S. thesis, 47 p. [1 tab., 11 pls., 6 figs.]

Baltusis, M.A., Quigley, M.F., and Mandle, R.J., 1992, Municipal ground-water development and withdrawals in the central Lower Peninsula of Michigan, 1870-1987: U.S. Geological Survey Open-File Report 91-215, 89 p.

Ciner, A.T., 1988, Stratigraphic and depositional environment of the Bayport Limestone of the southern Michigan Basin: Toledo, Ohio, University of Toledo, M.S. thesis, 133 p. [2 tabs., 36 figs.]

Cohee, G.V., 1965, Geologic history of the Michigan Basin: Washington Academy of Science Journal, v. 55, p. 211-233.

1979, Michigan Basin region, in Paleotectonic investigations of the Mississippian System in the United States, part I--Introduction and regional analyses of the Mississippian System: U.S. Geological Survey Professional Paper 1010, p. 49-57.

Cohee, G.V., Burns, R.N., Brown, Andrew, Brant, R.A., and Wright, Dorothy, 1950, Coal resources of Michigan: U.S. Geological Survey Circular 77, 56 p.

Cohee, G.V., Macha, Carol, and Holk, Margery, 1951, Thickness and lithology of Upper Devonian and Carboniferous rocks: U.S. Geological Survey, Oil and Gas Investigations Preliminary Chart OC-41.

Dannemiller, G.T., and Baltusis, M.A., Jr., 1990, Physical and chemical data for ground water in the Michigan Basin: U.S. Geological Survey Open-File Report 90-368, 155 p.

Dorr, J.A., Jr., and Eschman, D.F., 1970, Geology of Michigan: Ann Arbor, Mich., University of Michigan Press, $476 \mathrm{p}$.

Ells, G.D., 1979, Michigan, in the Mississippian and Pennsylvanian (Carboniferous) Systems in the United States: U.S. Geological Survey Professional Paper 1110, p. J1-J17.

Harrell, J.A., Hatfield, C.B., and Gunn, G.R., 1991, Mississippian System of the Michigan Basin; stratigraphy, sedimentology, and economic geology, in Catacosinos, P.A., and Daniels, P.A., eds., Early sedimentary evolution of the Michigan Basin: Geological Society of America Special Paper 256, p. 203-219.

Hearst, J.R., and Nelson, P.H., 1985, Well logging for physical properties: New York, McGraw-Hill, 571 p.

Hilchie, D.W., 1979, Old electric log interpretation: Golden, Colo., D.W. Hilchie, 161 p.

Kelly, W.A., 1936, The Pennsylvanian System of Michigan, in Occasional papers on the geology of Michigan: Michigan Geological Survey, Publication 40, Geological Series 34, pt. 2, 71 p.

Lane, A.C., 1899, Water resources of the Lower Peninsula of Michigan: U.S. Geological Survey WaterSupply Paper 30, $97 \mathrm{p}$.

1900, The coal basin of Michigan: Engineering Mining Bulletin, v. 69, p. 767-768.

1902a, Third annual report of the State Geologist for the year 1901: Michigan Geological Survey Annual Report, 1901, 304 p.

1902b, The northern interior coal field: U.S. Geological Survey Annual Report, v. 22, pt. III, p. 313-331.

1905, Fifth annual report of the State Geologist for the year 1903: Michigan Geological Survey Annual Report 1903, 342 p.

Lasemi, Yaghoob, 1975, Subsurface geology and stratigraphic analysis of the Bayport Formation in the Michigan Basin: East Lansing, Mich., Michigan State University, M.S. thesis, 54 p. [1 tab., 12 figs.]

20 Hydrogeologic Framework of Pennsylvanian and Late Mississippian Rocks in the Central Lower Peninsula of Michigan 
Lilienthal, R.T., 1978, Stratigraphic cross-sections of the Michigan Basin: Michigan Geological Survey Report of Investigations 19, 33 p., 89 pls.

Mandle, R.J., 1986, Plan of study for the Regional Aquifer Systems Analysis of the Michigan Basin: U.S. Geological Survey Open-File Report 86-493, 23 p.

Mandle, R.J., and Westjohn, D.B., 1989, Geohydrologic framework and ground-water flow in the Michigan Basin, in Swain L.A., and Johnson, A.I., eds., Regional aquifer systems of the United States, aquifers of the Midwestern area: American Water Resources Monograph Series No. 13, p. 83-109.

Martin, H.M., 1936, The centennial geological map of Michigan (2 sheets, Southern and Northern Peninsula): Michigan Geological Survey, Publication 39, Geological Series 33, scale 1:500,000.

Martin, H.M., and Straight, M.T., 1956, An index of the geology of Michigan 1823-1955: Michigan Department of Conservation, Publication 50, 461 p., 13 pls.

Martin, J.R., 1982, Pennsylvanian deltaic sedimentation in Grand Ledge, Michigan: Kalamazoo, Mich., Western Michigan University, M.S. thesis, 131 p. [43 figs.]

Michigan Geological Survey, 1964, Stratigraphic succession in Michigan, Paleozoic through recent: Chart 1.

Milstein, R.L., 1987, Bedrock geology of southern Michigan: Michigan Geological Survey, scale 1:500,000.

Newcombe, R.B., 1933, Oil and gas fields of Michigan: Michigan Geological Survey, Publication 38, Geological Series 32, 293 p.

Shideler, G.L., 1969, Dispersal patterns of Pennsylvanian sandstones in the Michigan Basin: Journal of Sedimentary Petrology, v. 39, no. 3, p. 1229-1237.

Strutz, T.A., 1978, A pre-Pennsylvanian paleogeologic study of Michigan: East Lansing, Mich., Michigan State University, M.S. thesis, 68 p. [8 pls., 9 figs.]

Tyler, J.G., 1980, Subsurface geology and depositional systems of the Upper Mississippian-Lower Pennsylvanian Bayport and Saginaw Formations, Central Michigan basin: Detroit, Mich., Wayne State University, M.S. thesis, 133 p. [15 figs., 2 pls.]

Vanlier, K.E., and Wheeler, M.L., 1968, Analog simulation of ground-water development of the Saginaw Formation, Lansing Metropolitan area, Michigan: U.S. Geological Survey, in cooperation with Tri-County Planning Commission and Michigan Geological Survey, 40 p.

Vanlier, K.E., Wood, W.W., and Brunett, J.O., 1973, Water supply development and management alternatives for Clinton, Eaton, and Ingham Counties, Michigan: U.S. Geological Survey Water-Supply Paper 1969, $111 \mathrm{p}$.

Velbel, M.A., and Brandt, D.S., 1989, Sedimentology and paleogeography of Grand Ledge: Michigan Basin Geological Society, Spring 1989 field trip guide, 33 p.

Vugrinovich, Ray, 1984, Lithostratigraphy and depositional environments of the Pennsylvanian rocks and the Bayport Formation of the Michigan Basin: Michigan Geological Survey, Report of Investigation 27, 33 p.

Wanless, H.R., and Shideler, G.L., 1975, Michigan Basin region, in McKee, E.D., and Crosby, E.J., coordinators, Paleotectonic investigations of the Pennsylvanian System in the United States, part 1-Introduction and regional analysis of the Pennsylvanian System: U.S. Geological Survey Professional Paper 853, p. 61-70.

Weeks, J.B., and Sun, R.J., 1987, Regional Aquifer-System Analysis Program of the U.S. Geological Survey-bibliography, 1978-86: U.S. Geological Survey Water-Resources Investigations Report 87-4138, 81 p.

Weller, J.M., 1930, Cyclical sedimentation of the Pennsylvanian Period and its significance: Journal of Geology, v. 38, p. 97-135.

Western Michigan University, Department of Geology, 1981, Hydrogeologic atlas of Michigan: U.S. Environmental Protection Agency Underground Injection Control Program Report, 35 pls., scale 1:500,000.

Westjohn, D.B., 1989, Application of geophysics in the delineation of the freshwater/saline water interface in the Michigan Basin, in Swain, L.A., and Johnson, A.I., eds., Regional aquifer systems of the United States, aquifers of the Midwestern area: American Water Resources Association Monograph Series No. 13 , p. 111-134.

1993, Geological controls of distribution of freshwater in aquifers of the Michigan basin [abs.], in Michigan--Its Geology and Geologic Resources, 3d symposium, Michigan State University, East Lansing, Mich., March 18-19, 1993: Program and abstracts, p. 10. 
1994, Geologic controls of the distribution of freshwater in a regional aquifer system--cental Michigan Basin: Geological Society of America Abstracts with Programs, v. 26, no. 5, p. 67.

Westjohn, D.B., Olsen, H.W., and Willden, A.T., 1990, Matrix-controlled hydraulic properties of Mississippian and Pennsylvanian sandstones from the Michigan Basin: U.S. Geological Survey Open-File Report 90-104, 19 p.

Westjohn, D.B., Sibley, D.F., and Eluskie, J.A., 1991, Authigenic mineral paragenesis in Mississippian and Pennsylvanian sandstone aquifers in the Michigan Basin [abs.]: Geological Society of America Abstracts with Programs, v. 23, no. 5, p. 26.

Westjohn, D.B., and Weaver, T.L., in press, Hydrogeologic framework of Mississippian rocks in the central Lower Peninsula of Michigan: U.S. Geological Survey Water-Resources Investigations Report 94-4246, $40 \mathrm{p}$.

Westjohn, D.B., Weaver, T.L., and Zacharias, K.F., 1994, Hydrogeology of Pleistocene glacial deposits and Jurassic "red beds" in the central Lower Peninsula of Michigan: U.S. Geological Survey Water-Resources Investigations Report 93-4152, 14 p.

Winchell, Alexander, 1861, Geology, zoology, and botany of the Lower Peninsula: First Biennial Report of the Progress of the Geological Survey of Michigan, $339 \mathrm{p}$.

1869, Map of the State of Michigan colored to show the geologic formations, in Atlas of the State of Michigan. [Tackabury Atlas.] 


\section{APPENDIXES}





\section{APPENDIX A. IDENTIFICATION AND LOCATIONS OF GEOPHYSICAL AND \\ GEOLOGIC LOGS, AND GENERALIZED HYDROGEOLOGIC SECTIONS \\ ILLUSTRATING RELATIONS OF AQUIFER AND CONFINING UNITS}

\section{CONTENTS}

Table A1. Identification of geophysical and geologic logs used to construct hydrogeologic section A-A', Muskegon County to Crawford County, Michigan $\ldots \ldots \ldots \ldots \ldots \ldots \ldots \ldots \ldots \ldots$

Table A2. Identification of geophysical and geologic logs used to construct hydrogeologic section B-B', Wexford County to Shiawassee County, Michigan $\ldots \ldots \ldots \ldots \ldots \ldots \ldots \ldots \ldots$

Figure A1. Map showing location of geophysical and geologic logs used to construct hydrogeologic sections A-A' and B-B', central Lower

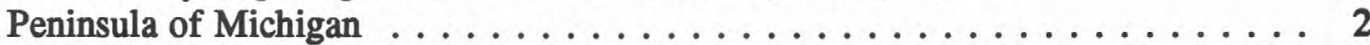

Figure A2. Generalized hydrogeologic section A-A' showing stratigraphic relations of Mississippian and younger geologic units, Muskegon County to Crawford County, Michigan . . . . . . . . . . . . . . . . . . 30

Figure A3. Generalized hydrogeologic section B-B' showing stratigraphic relations of Mississippean and younger geologic units, Wexford County to Shiawassee County, Michigan . . . . . . . . . . . . . . . . . . 31 

Table A1. Identification of geophysical and geologic logs used to construct hydrogeologic section A-A : Muskegon County to Crawford County, Michigan

[Abbreviations: USGS, U.S. Geological Survey; Permit numbers are assigned to oil and gas wells by Michigan Department of Natural Resources; dashea indicate that no permit number was issued, or well was used for purposes other than oil or gas exploration or production. USGS identifiens are numbers assigned to logs on file at USGS, indicating county where well is located, type of well, and type of log]

\begin{tabular}{|c|c|c|c|c|}
\hline $\begin{array}{l}\text { Permit } \\
\text { number }\end{array}$ & $\begin{array}{c}\text { Number on } \\
\text { geologic } \\
\text { section }\end{array}$ & $\begin{array}{l}\text { USGS } \\
\text { identifier }\end{array}$ & $\begin{array}{l}\text { Section } \\
\text { Townehip } \\
\text { Range }\end{array}$ & Township name, county \\
\hline 18227 & 1 & Mk-g12 & $13-11 N-18 W$ & Fruitland, Muskegon \\
\hline- & 2 & Mk-W11 & $16-11 \mathrm{~N}-17 \mathrm{~W}$ & Fruitland, Muskegon \\
\hline 1499 & 3 & Mk-g9 & $03-11 N-16 W$ & Dalton, Muskegon \\
\hline- & 4 & $\mathbf{R} 2$ & $30-12 N-15 W$ & Holton, Muskegon \\
\hline 217 & 5 & Mk-g16 & $13-12 \mathrm{~N}-15 \mathrm{~W}$ & Holton, Muskegon \\
\hline 16718 & 6 & $\mathrm{Nw}-7$ & $01-12 N-14 W$ & Bridgeton, Newaygo \\
\hline 13520 & 7 & $\mathrm{Nw}-5$ & $10-12 N-13 W$ & Garfield, Newaygo \\
\hline 13719 & 8 & $\mathrm{Nw}-21$ & $11-12 N-13 W$ & Garfield, Newaygo \\
\hline 13264 & 9 & $\mathrm{Nw}-25$ & $13-12 N-13 W$ & Garfield, Newaygo \\
\hline- & 10 & Nw-W3 & $16-12 N-12 W$ & Brooks, Newaygo \\
\hline 13146 & 11 & $N w-29$ & $33-13 N-11 W$ & Big Prairie, Newaygo \\
\hline 16245 & 12 & Mt-32 & $05-13 N-10 W$ & Aetna, Mecosta \\
\hline 16305 & 13 & Mt-3 & $03-13 N-10 W$ & Aetna, Mecosta \\
\hline 16005 & 14 & Mt-16 & $26-14 \mathrm{~N}-10 \mathrm{~W}$ & Mecosta, Mecosta \\
\hline 34622 & 15 & Mt-N3 & $04-14 \mathrm{~N}-09 \mathrm{~W}$ & Austin, Mecosta \\
\hline 11775 & 16 & Mt-5 & $23-15 N-09 W$ & Colfax, Mecosta \\
\hline 9806 & 17 & Mt-11 & $17-15 N-08 W$ & Martiny, Mecosta \\
\hline 12018 & 19 & Mt-22 & $12-16 \mathrm{~N}-08 \mathrm{~W}$ & Chippewa, Mecosta \\
\hline 11061 & 20 & Mt-28 & $12-16 \mathrm{~N}-08 \mathrm{~W}$ & Chippewa, Mecosta \\
\hline 16335 & 21 & Os-6 & $34-17 \mathrm{~N}-07 \mathrm{~W}$ & Orient, Osceola \\
\hline 12868 & 22 & $\mathrm{Cl}-13$ & $22-17 \mathrm{~N}-06 \mathrm{~W}$ & Garfield, Clare \\
\hline 10498 & 23 & $\mathrm{Cl}-10$ & $06-17 \mathrm{~N}-05 \mathrm{~W}$ & Surrey, Clare \\
\hline 31670 & 24 & Cl-N5 & $21-18 \mathrm{~N}-05 \mathrm{~W}$ & Lincoln, Clare \\
\hline 10795 & 25 & $\mathrm{Cl}-18$ & $12-18 \mathrm{~N}-05 \mathrm{~W}$ & Lincoln, Clare \\
\hline 11946 & 26 & $\mathrm{Cl}-20$ & $06-18 \mathrm{~N}-04 \mathrm{~W}$ & Hatton, Clare \\
\hline 14759 & 27 & $\mathrm{Cl}-17$ & $36-20 \mathrm{~N}-04 \mathrm{~W}$ & Frost, Clare \\
\hline 15433 & 28 & $\mathrm{Cl}-3$ & $19-20 \mathrm{~N}-03 \mathrm{~W}$ & Franklin, Clare \\
\hline 16985 & 29 & Rc-9 & $29-21 N-03 W$ & Roscommon, Roscommon \\
\hline 15702 & 30 & Rc-2 & $20-21 N-03 W$ & Roscommon, Roscommon \\
\hline 39826 & 31 & Rc-g3 & $23-22 N-03 W$ & Denton, Roscommon \\
\hline 5521 & 32 & Rc-g64 & $06-22 \mathrm{~N}-02 \mathrm{~W}$ & Bachus, Roscommon \\
\hline 16683 & 33 & Rc-g8 & $21-24 N-02 W$ & Higgins, Roscommon \\
\hline- & 34 & Rc-g7 & $02-24 \mathrm{~N}-02 \mathrm{~W}$ & Higgins, Roscommon \\
\hline 7864 & 35 & Rc-g17 & $36-23 N-01 W$ & Richfield, Roscommon \\
\hline- & 36 & R5 & $12-25 \mathrm{~N}-02 \mathrm{~W}$ & South Branch, Crawford \\
\hline
\end{tabular}


Table A2. Identification of geophysical and geologic logs used to construct hydrogeologic section B-B', Wexford County to Shiawassee County, Michigan

[Abbreviations: USGS, U.S. Geological Survey; Permit numbers are assigned to oil and gas wells by Michigan Department of Natural Reaources; dashes indicate that no permit number wes iseued, or well was usod for purpowes other than oil or gas exploration or production. USGS identifiers are numbers assigned to logs on file at USGS, indicating county where well is located, type of well, and type of log]

\begin{tabular}{|c|c|c|c|c|}
\hline $\begin{array}{l}\text { Permit } \\
\text { number }\end{array}$ & $\begin{array}{l}\text { Number on } \\
\text { geologic } \\
\text { section }\end{array}$ & $\begin{array}{l}\text { USGS } \\
\text { identifier }\end{array}$ & $\begin{array}{l}\text { Section } \\
\text { Townahip } \\
\text { Range }\end{array}$ & Townehip name, county \\
\hline 29755 & 1 & $W x-g 20$ & $16-24 \mathrm{~N}-11 \mathrm{~W}$ & Hanover, Wexford \\
\hline 10303 & 2 & $W x-3$ & $11-23 N-11 W$ & Antioch, Wexford \\
\hline 35866 & 3 & Wx-N1 & $05-23 N-10 \mathrm{~W}$ & Colfax, Wexford \\
\hline 12304 & 4 & $W x-4$ & $11-22 \mathrm{~N}-10 \mathrm{~W}$ & Selma, Wexford \\
\hline 10661 & 5 & Wx-g58 & $24-22 \mathrm{~N}-10 \mathrm{~W}$ & Selma, Wexford \\
\hline 18209 & 6 & $W x-6$ & $36-22 \mathrm{~N}-10 \mathrm{~W}$ & Selma, Wexford \\
\hline 20742 & 7 & Wx-5 & $13-21 N-10 W$ & Cherry Grove, Wexford \\
\hline 10754 & 8 & Os-8 & $09-20 \mathrm{~N}-09 \mathrm{~W}$ & Sherman, Osceola \\
\hline 25007 & 9 & Os-g15 & $14-20 \mathrm{~N}-09 \mathrm{~W}$ & Sherman, Osceola \\
\hline 15934 & 10 & Os-9 & $19-20 \mathrm{~N}-08 \mathrm{~W}$ & Highland, Osceola \\
\hline - & 11 & Os-24 & $34-20 \mathrm{~N}-09 \mathrm{~W}$ & Sherman, Osceola \\
\hline 14591 & 12 & Os-31 & $29-20 N-08 W$ & Highland, Osceola \\
\hline 11670 & 13 & Os-1 & $19-19 \mathrm{~N}-08 \mathrm{~W}$ & Hartwick, Osceola \\
\hline 9039 & 14 & Os-g97 & $25-19 \mathrm{~N}-08 \mathrm{~W}$ & Hartwick, Osceola \\
\hline 8573 & 15 & Os-g65 & $07-18 N-07 W$ & Sylvan, Osceola \\
\hline 14639 & 16 & Os-4 & $09-18 \mathrm{~N}-07 \mathrm{~W}$ & Sylvan, Osceola \\
\hline 32394 & 17 & Os-N1 & $03-17 N-07 W$ & Orient, Osceola \\
\hline 13739 & 18 & Os-12 & $03-17 \mathrm{~N}-07 \mathrm{~W}$ & Orient, Osceola \\
\hline 12375 & 19 & Os-29 & $12-17 \mathrm{~N}-07 \mathrm{~W}$ & Orient, Osceola \\
\hline 26256 & 20 & Ib-g45 & $10-16 \mathrm{~N}-06 \mathrm{~W}$ & Coldwater, Isabella \\
\hline 12911 & 21 & $\mathrm{Ib}-65$ & $20-16 \mathrm{~N}-06 \mathrm{~W}$ & Coldwater, Isabella \\
\hline 11747 & 22 & Ib-13 & $02-15 \mathrm{~N}-06 \mathrm{~W}$ & Sherman, Isabella \\
\hline 18330 & 23 & Ib-57 & $13-15 \mathrm{~N}-06 \mathrm{~W}$ & Sherman, Isabella \\
\hline 23980 & 24 & Ib-L1 & $16-14 \mathrm{~N}-05 \mathrm{~W}$ & Deerfield, Isabella \\
\hline 15597 & 25 & Ib-6 & $01-14 \mathrm{~N}-05 \mathrm{~W}$ & Deerfield, Isabella \\
\hline 16275 & 26 & Ib-7 & $17-14 \mathrm{~N}-04 \mathrm{~W}$ & Union, Isabella \\
\hline - & 27 & Ib-W2 & $27-14 \mathrm{~N}-04 \mathrm{~W}$ & Union, Isabella \\
\hline 16791 & 28 & Ib-10 & $28-13 \mathrm{~N}-04 \mathrm{~W}$ & Lincoln, Isabella \\
\hline 9464 & 29 & Gr-g23 & $13-12 N-04 W$ & Seville, Gratiot \\
\hline - & 30 & Gr-W11 & $30-11 \mathrm{~N}-02 \mathrm{~W}$ & Emerson, Gratiot \\
\hline 10536 & 31 & Gr-3 & $36-11 N-03 W$ & Arcada, Gratiot \\
\hline 14844 & 32 & Gr-2 & $26-10 \mathrm{~N}-03 \mathrm{~W}$ & Newark, Gratiot \\
\hline 13920 & 33 & Gr-1 & $36-10 N-03 W$ & Newark, Gratiot \\
\hline 33991 & 34 & Gr-NFD-1 & $28-10 \mathrm{~N}-02 \mathrm{~W}$ & North Star, Gratiot \\
\hline 33382 & 35 & Gr-NFD-4 & $22-09 \mathrm{~N}-02 \mathrm{~W}$ & Washington, Gratiot \\
\hline 3703 & 36 & Gr-g79 & $36-10 \mathrm{~N}-01 \mathrm{~W}$ & Hamilton, Gratiot \\
\hline 33313 & 37 & $\mathrm{Ct}-\mathrm{N} 2$ & $24-08 \mathrm{~N}-02 \mathrm{~W}$ & Greenbush, Clinton \\
\hline 33321 & 38 & Ct-N1 & $09-07 \mathrm{~N}-01 \mathrm{~W}$ & Ovid, Clinton \\
\hline 3586 & 39 & Ct-g21 & $25-07 \mathrm{~N}-01 \mathrm{~W}$ & Ovid, Clinton \\
\hline 1198 & 40 & Sw-g2 & $01-05 N-01 E$ & Woodhull, Shiawassee \\
\hline 23376 & 41 & Sw-g9 & $25-05 N-02 E$ & Perry, Shiawassee \\
\hline
\end{tabular}

28 Hydrogeologic Framework of Pennsylvanian and Late Mississippian Rocks in the Central Lower Peninsula of Michigan 


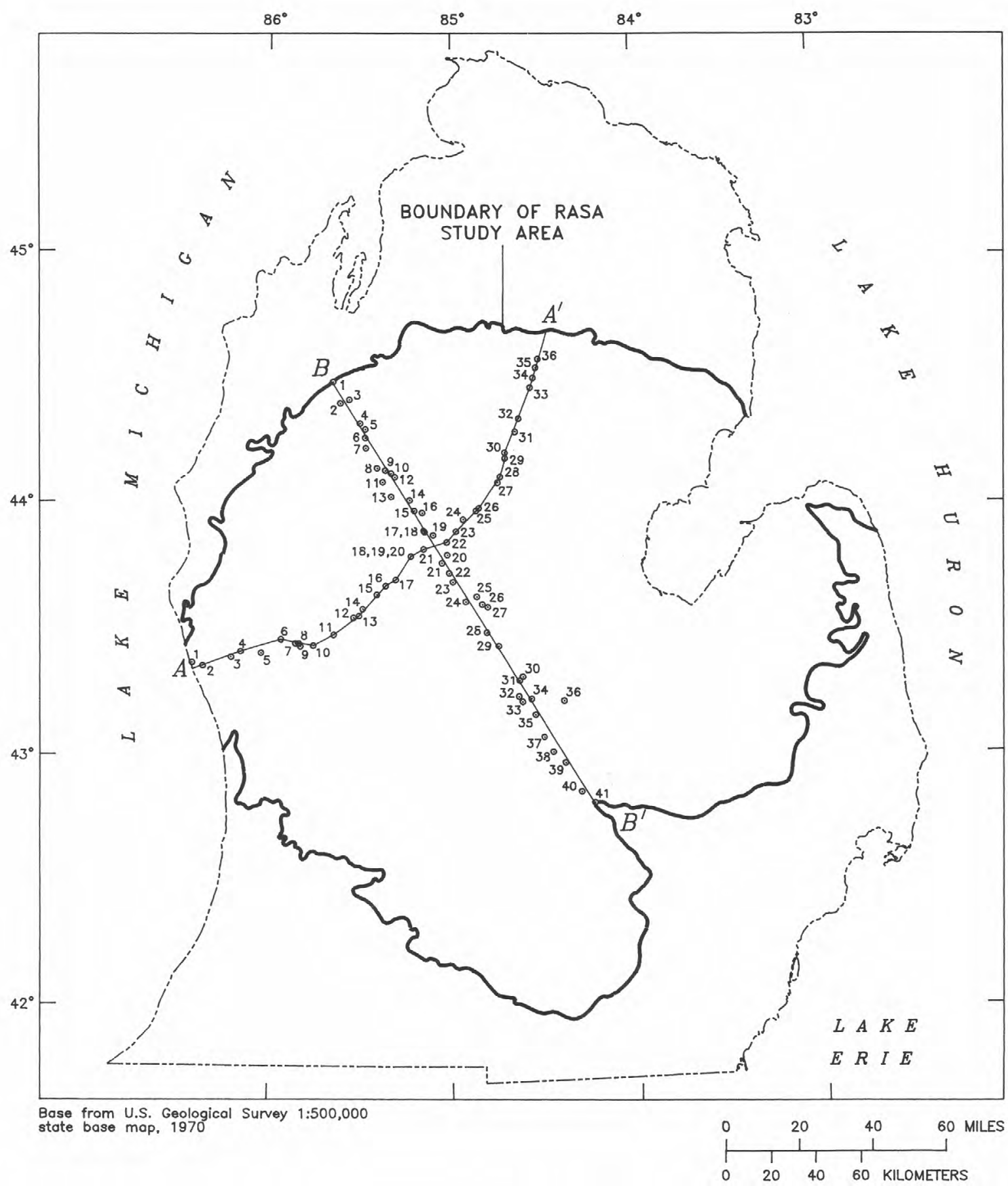

EXPLANATION

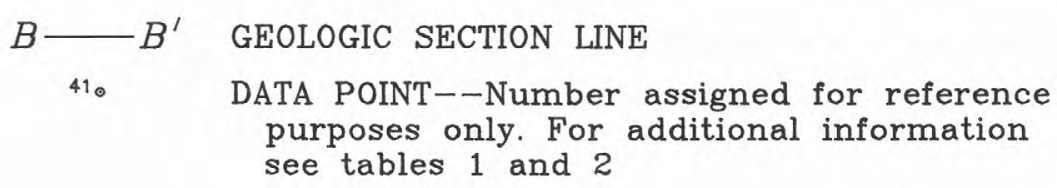

Figure A1. Location of geophysical and geologic logs used to construct hydrogeologic sections A-A' and B-B', central Lower Peninsula of Michigan. 


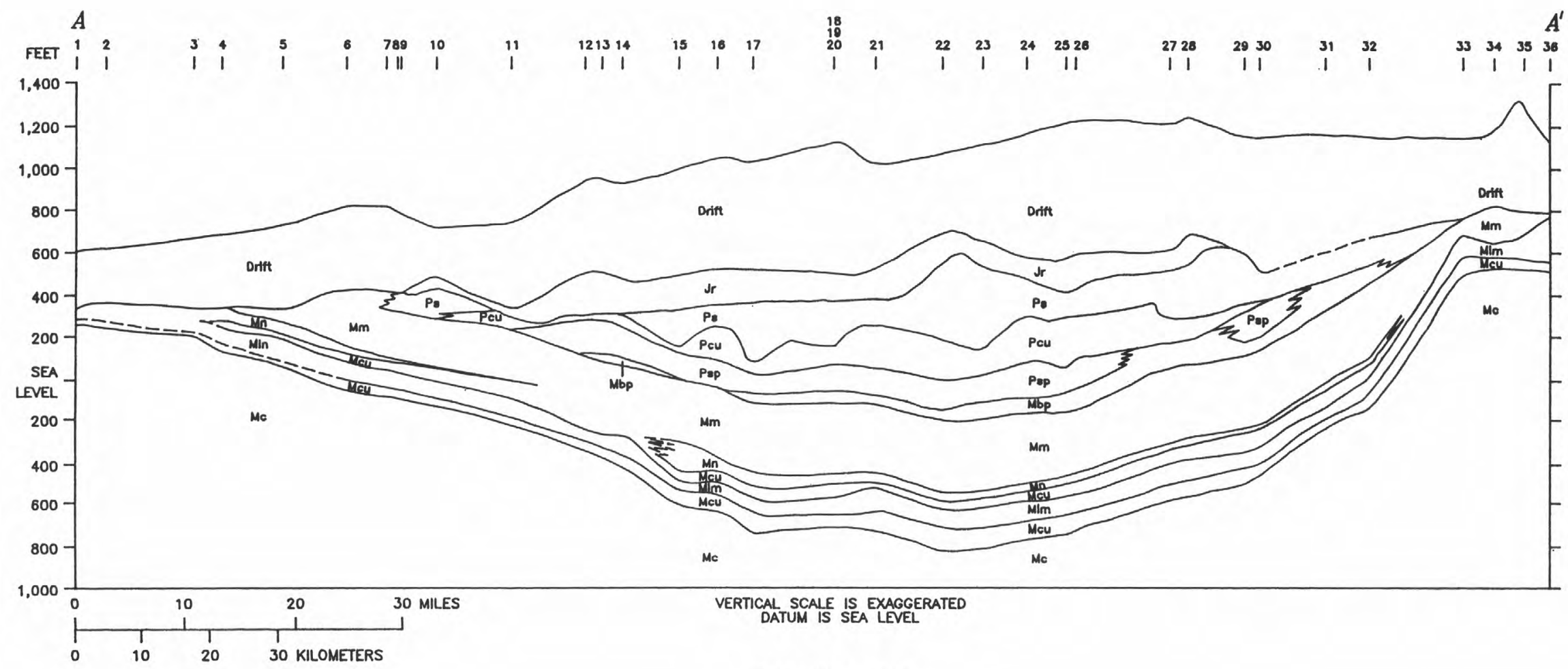

\section{EXPLANATION}

FORMATION

Drift Drift--Glacial deposits (undifferentiated)

GEOLOGIC CONTACT--Dashed where approximately located LOCATION OF LOGGED BOREHOLE--Refer to Appendix 1, table 1, column 2

"Red Beds"

Grand River-Saginaw Formations

\section{$\sqrt{\mathrm{r}}$}

$\mathrm{Pcu}$

PSP

MbP

$\mathrm{Mm}$

$\mathrm{Mn}$

Mim

Mau (undifferentiated)

Saginaw Formation (principally shale)

Parma Sandstone

Bayport Limestone

Michigan Formation

Marshall Sandstone (Napoleon member)

Marshall Sandstone (lower Marshall unit)

Marshall Sandstone (confining unit lithologies)

Coldwater Shale
PERIOD OR SERIES

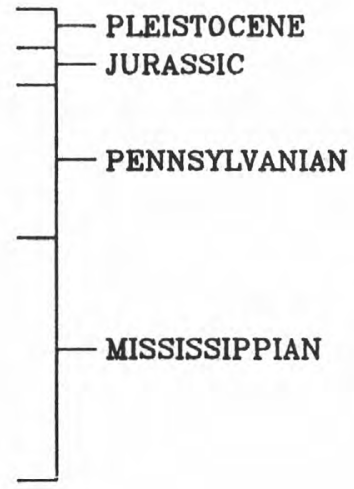

Figure A2. Generalized hydrogeologic section $A-A^{\bullet}$ showing stratigraphic relations of Mississippian and younger geologic units, Muskegon County to Crawford County, Michigan. (Line of section shown in fig. A1.) 


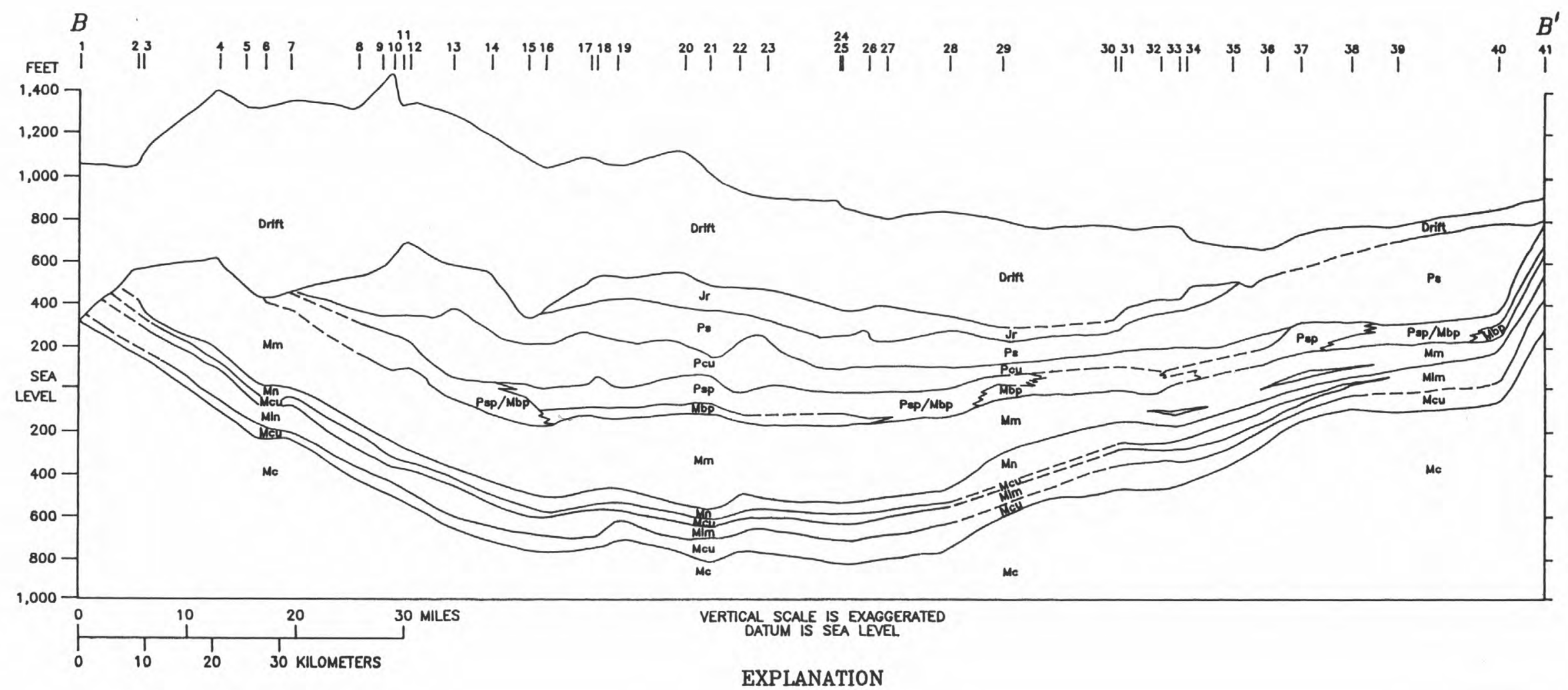

\section{FORMATION}

[Dritt

$\frac{\mathrm{Jr}}{\mathrm{P}_{\mathrm{s}}}$ approximately located

LOCATION OF LOGGED BOREHOLE--Refer to Appendix 1, table 2, column 2
Drift--Glacial deposits (undifferentiated)

"Red Beds"

Grand River-Saginaw Formations (undifferentiated)

Saginaw Formation (principally shale)

Parma Sandstone

Bayport Limestone

Michigan Formation

Marshall Sandstone (Napoleon member)

Marshall Sandstone (lower Marshall unit)

Marshall Sandstone (confining unit lithologies)

Coldwater Shale
PERIOD OR SERIES

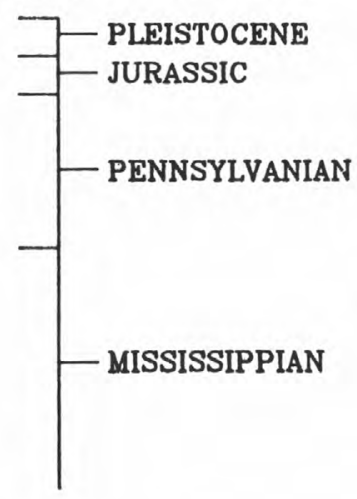

Figure A3. Generalized hydrogeologic section B-B' showing stratigraphic relations of Mississippian and younger geologic units, Wexford County to Shiawassee County, Michigan. (Line of section shown in fig. A1.) 

APPENDIX B. INTERPRETATION OF GEOPHYSICAL AND GEOLOGIC LOGS

\section{CONTENTS}

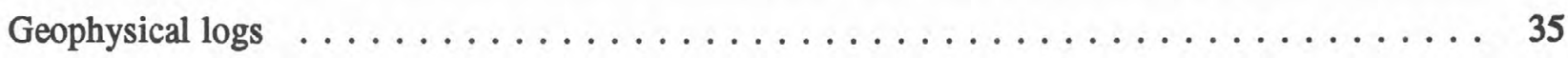

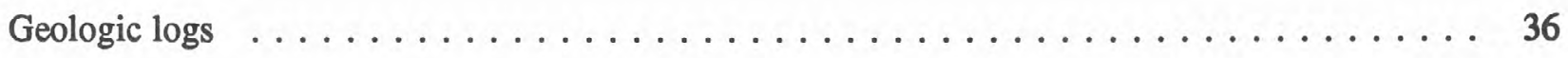

Figure B1. Sample suite of geophysical logs showing typical electric-log, gamma-ray, and porosity-log traces of selected Pennsylvanian and Late Mississippian rock units in the central Lower Peninsula of

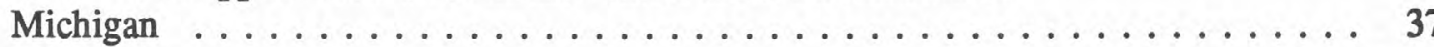





\section{GEOPHYSICAL LOGS}

Production of oil and gas in the Michigan Basin began in 1925 (Dorr and Eschman, 1970, p.237), and Michigan continues to be a major producer of hydrocarbons. Geophysical logging of hydrocarbon-exploration boreholes became common practice in the 1940's. RASA investigators located approximately 300 electrical-resistivity/spontaneous-potential logs (or old electric logs; Hilchie, 1979) of boreholes drilled before 1950, which were run in shallow-cased boreholes that were open to Pennsylvanian and Mississippian rocks. At many places, the logged boreholes were open to Pleistocene glacial deposits, which allows for characterization of geophysical properties of all units in the aquifer system. Discoveries of natural gas in Mississippian sandstones in the late 1950's resulted in continued exploration activity; most boreholes drilled after 1960 were logged with a suite of improved geophysical-logging tools, including caliper, gamma ray, dual induction or dual laterolog, neutron porosity, and density porosity. Westjohn (1989) included detailed discussion of applications of geophysical logs in the characterization of hydrostratigraphic units in the Michigan Basin regional aquifer system study area.

There are several advantages of using geophysical logs to map hydrostratigraphic units. Aquifers and confining units have distinct geophysical-log traces, as can be seen in figure B1.

Permeable lithologies can be identified on the basis of electrical-resistivity-log traces. Highdensity-drilling muds (densities greater than 9 grams per cubic centimeter) are commonly used during drilling of oil and gas wells. Filtrate from heavy-drilling mud typically displaces native pore fluid in permeable formations. The effects of infiltration of fluids from drilling mud can be measured with electrical-resistivity-logging tools. A common design of logging tools involves multiple electrode configurations that allow measurement of electrical resistivity at three distances laterally away from the borehole opening. One configuration of electrodes is designed to measure electrical resistivity very near the borehole in the flushed zone (area of total displacement of formation fluid by mud filtrate; Hearst and Nelson, 1985, p. 28-30). A second configuration measures electrical resistivity in the transition zone (area of mixing of formation fluid and mud filtrate), and a third configuration measures electrical resistivity in the noninvaded zone (true formation resistivity). In cases where formation fluid and mud filtrate have substantially different electrical resistivities (which is the general case in Michigan) and drilling fluid has invaded permeable strata, a separation of electrical-resistivity-log traces is observed. The separations of electrical-resistivity-log traces commonly observed in aquifers of the study area are illustrated by the example log (fig. B1). The amount of separation of the three traces recorded on electrical-resistivity logs is a function of formation permeability and the distance that fluid has infiltrated the formation, as well as the amount of contrast in electrical resistivity between formation fluid and mud filtrate.

Electric logs and combination geophysical-log suites (gamma ray, neutron porosity, density porosity, and dual resistivity) are available for much of the study area from the Oil and Gas Division, Michigan Geological Survey. Geophysical logs are numerous for some areas of the basin where discovery wells or indications of oil and gas stimulated exploration activities. Exploration boreholes in areas surrounding oil- and gas-discovery wells were also commonly logged.

Geophysical logs are sparse or nonexistent for most of the Thumb Area (fig. B1) and the southern part of the study area, with the exception of a few gamma-ray logs that were run in cased boreholes. 


\section{GEOLOGIC LOGS}

Geologic logs of oil, gas, and water wells are on file with the Michigan Geological Survey and the Michigan Department of Public Health. Geologic descriptions recorded on logs of oil, gas, and water wells (lithologic data, formation tops, and so forth) were used to map aquifer and confining boundaries in parts of the study area for which geophysical logs are sparse or unavailable. 


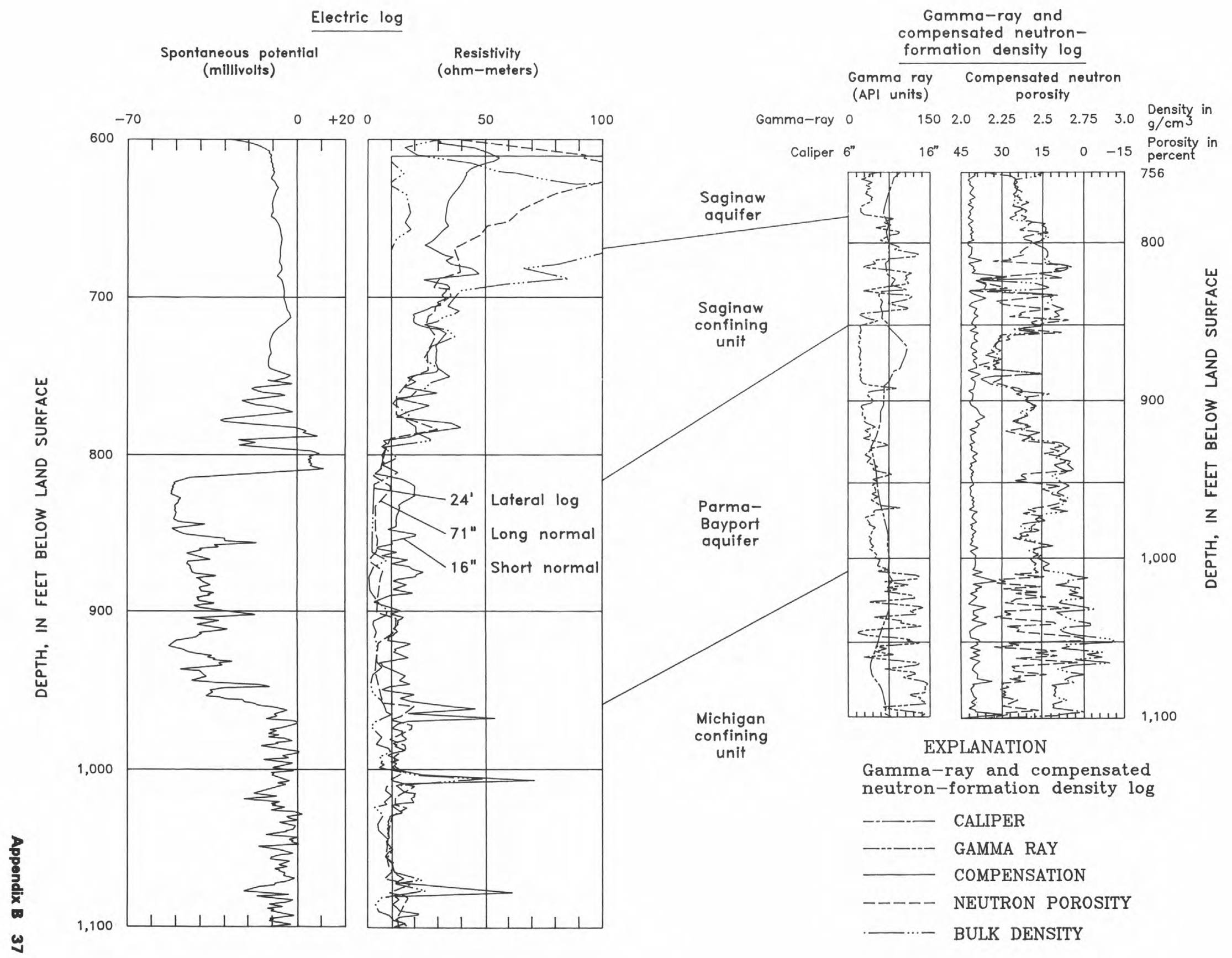

Figure B1. Sample suite of geophysical logs showing typical electric-log, gamma-ray, and porosity-log traces of selected Pennsylvanian and Late Mississippian rock units in the central Lower Peninsula of Michigan. 



\section{APPENDIX C. LOCATIONS OF BOREHOLES AND LOGS}

\section{CONTENTS}

Figures C1-C4 Maps showing:

C1. Locations of boreholes and logs used to construct surface-configuration and thickness maps of Pennsylvanian rocks, and thickness maps of Saginaw aquifer, central Lower Peninsula of Michigan . . . . . . . . . . . . . . . 41

C2. Locations of boreholes and geophysical logs used to construct thickness map of Saginaw confining unit, central Lower Peninsula

C3. Locations of boreholes and geophysical logs used to construct surface-configuration and thickness maps of Parma-Bayport aquifer, central Lower Peninsula of Michigan

C4. Locations of boreholes and geologic logs used to construct surface-configuration and thickness maps of Parma-Bayport aquifer, central Lower Peninsula of Michigan 



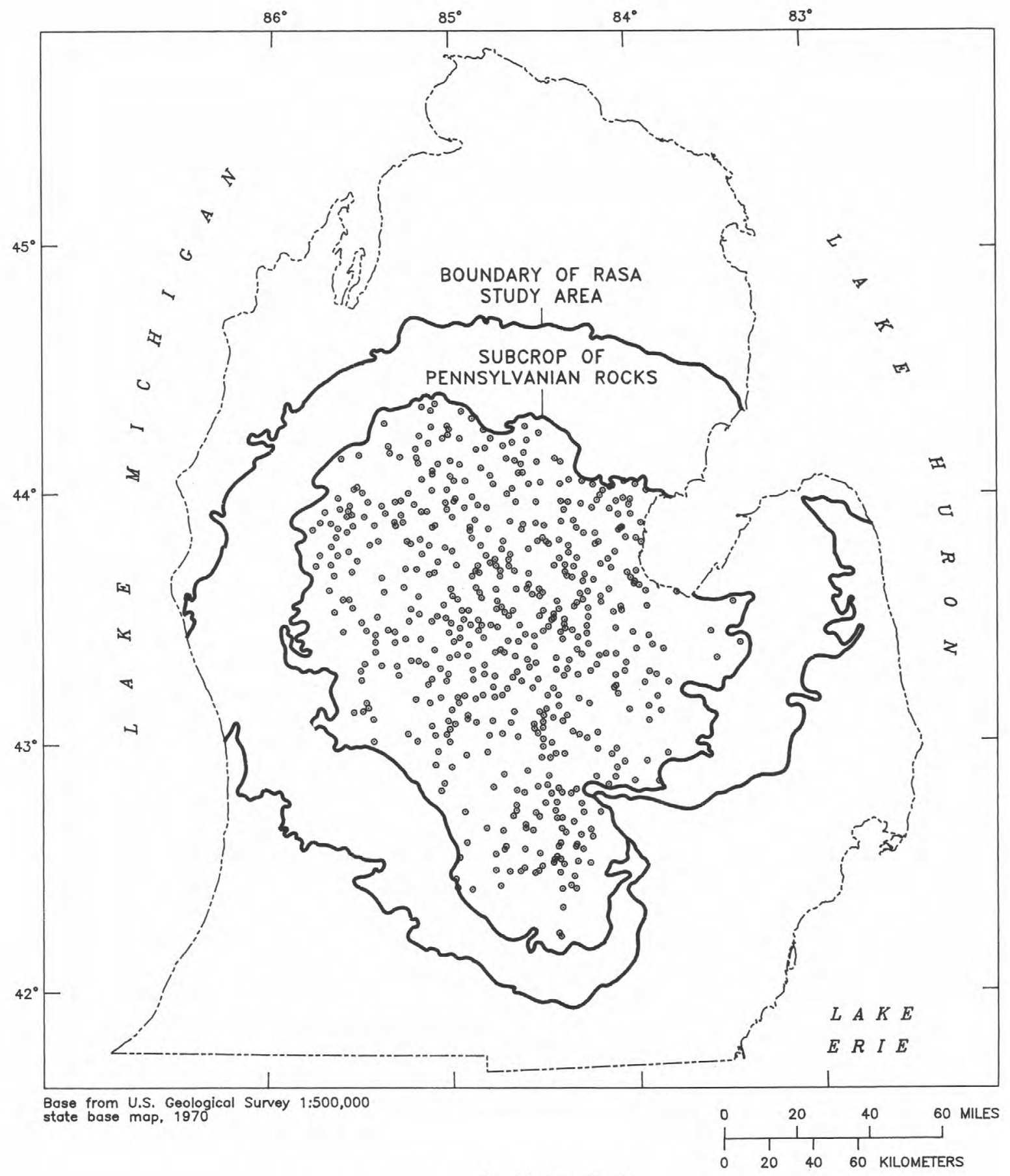

EXPLANATION

- DATA POINT--Shows location of boreholes and geologic logs used to construct figures 4,5 , and 6

Figure C1. Locations of boreholes and logs used to construct surface-configuration and thickness maps of Pennsylvanian rocks, and thickness map of Saginaw aquifer, central Lower Peninsula of Michigan. 


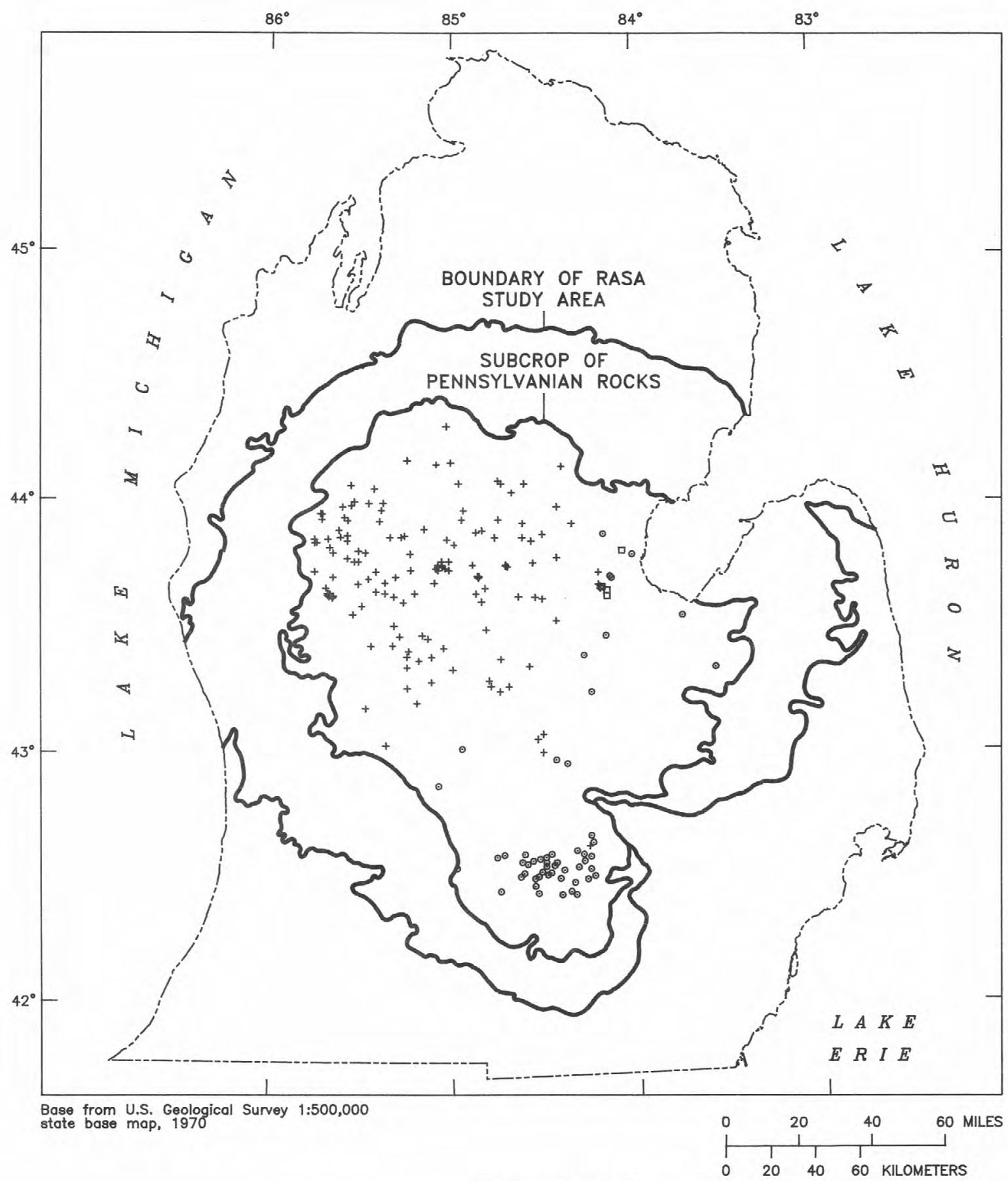

EXPLANATION

DATA POINT--Shows location of boreholes and type of $\log$ used to construct figure 7

- Gamma-ray log

+ Electric log

- Neutron $\log$

Figure C2. Locations of boreholes and geophysical logs used to construct thickness map of Saginaw confining unit, central Lower Peninsula of Michigan.

42 Hydrogeologic Framework of Pennsylvanian and Late Mississippian

Rocks in the Central Lower Peninsula of Michigan 


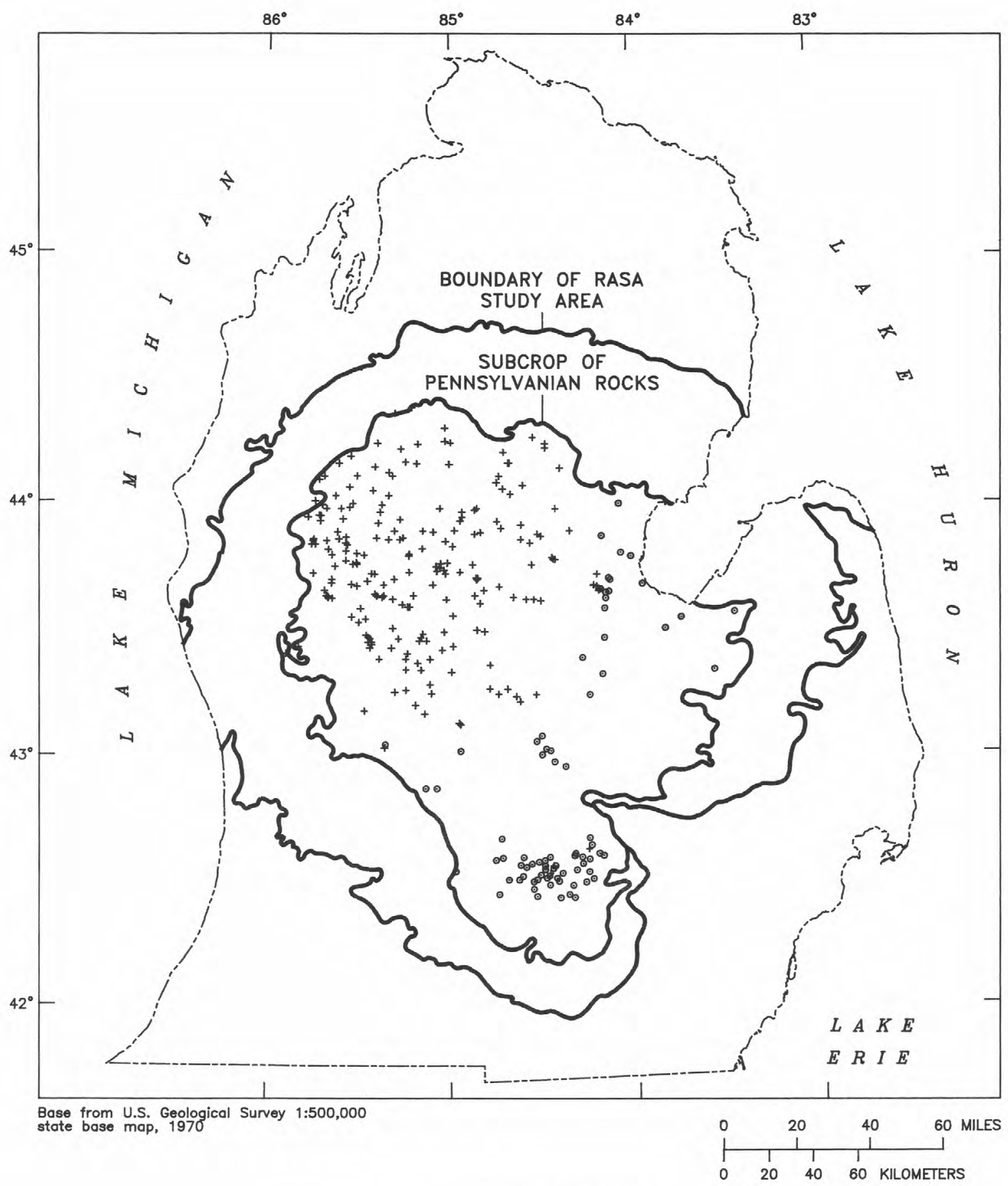

EXPLANATION

DATA POINT--Shows location of boreholes and type of $\log$ used to construct figurs 8 and 9

- Gamma-ray log

+ Electric log

Figure C3. Locations of boreholes and geophysical logs used to construct surface-configuration and thickness maps of Parma-Bayport aquifer, central Lower Peninsula of Michigan. 


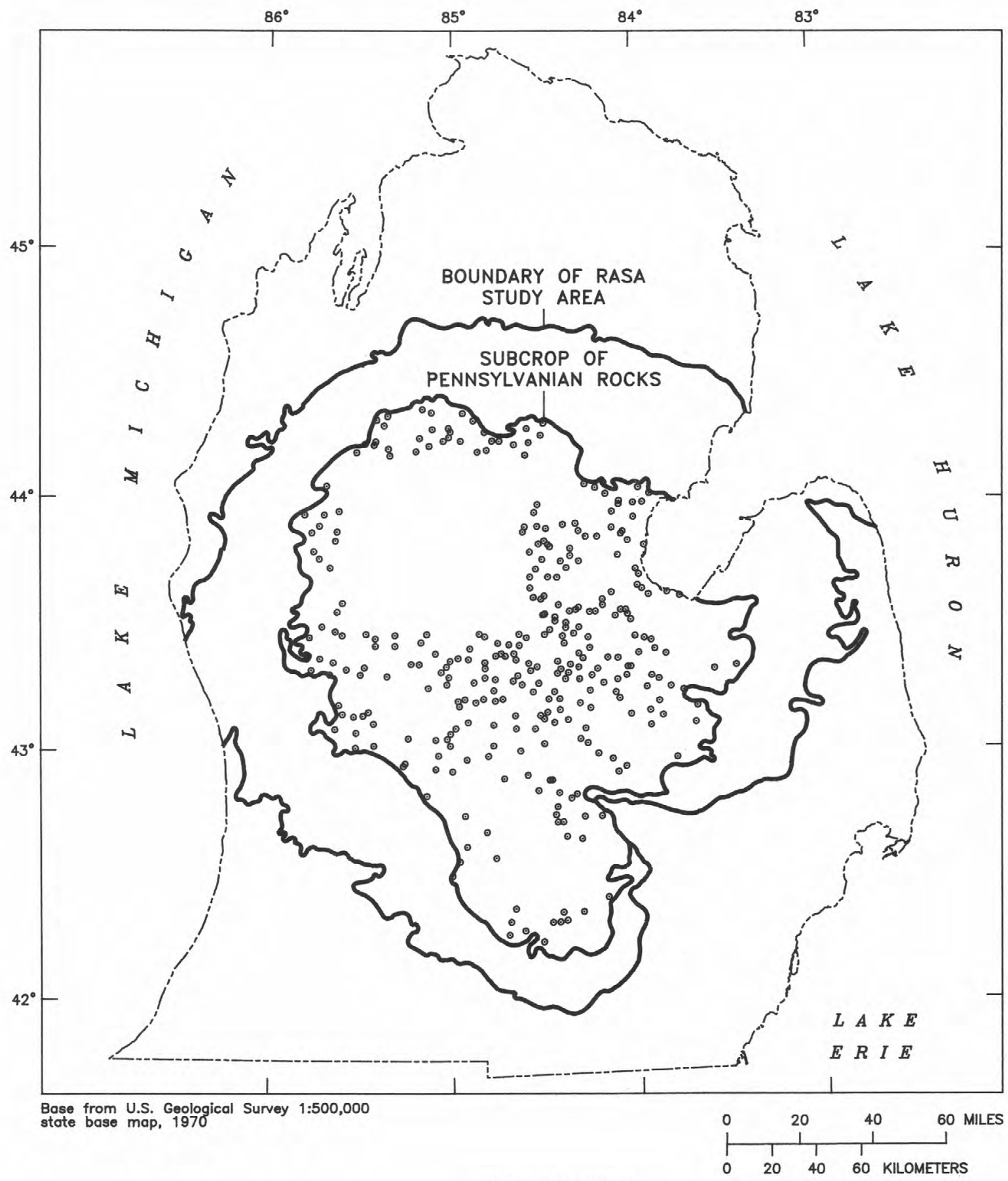

EXPLANATION

- DATA POINT--Shows location of boreholes and geologic logs used to construct figures 8 AND 9

Figure C4. Locations of boreholes and geologic logs used to construct surface-configuration and thickness maps of Parma-Bayport aquifer, central Lower Peninsula of Michigan. 

